\title{
Rebelión y carnaval \\ Ingaguasi (San Pedro de Atacama) 1775-1777
}

Jorge Hidalgo L. ${ }^{2}$ y Nelson Castro F. ${ }^{3}$

\section{RESUMEN}

Este artículo analiza el contexto, la percepción y las motivaciones étnicas en la rebelión de Carnestolendas, ocurrida en el mineral de Ingaguasi en 1775, cuyos efectos perduraron hasta 1777.

\section{ABSTRACT}

This articule analize the context, perception and ethnic motivation in Carnestolendas Rebellion, occurs in Ingaguasi mineral in 1775, which consequences where present until 1777.

\section{Introducción}

En algunas casas del asiento minero de Santa Loreto de Ingaguasi, jurisdicción de la antigua provincia de Atacama, colgaban, ondeando de las puertas, gallardetes de sargal, y por las calles se confundía una pequeña multitud de indios, mestizos y españoles.

Corrían los últimos días del mes de febrero de

Este trabajo forma parte del proyecto FONDECYT 1980638 "Historia de los pueblos andinos de Arica, Tarapacá y Atacama: Comunidades, cacicazgos y estado", cuyo investigador responsable es Jorge Hidalgo L. Una versión preliminar fue presentada en las III Jornadas del Norte de Chile realizada los días 13 y 14 de octubre de 1999 en el Instituto de Estudios Humanísticos de la Universidad de Valparaíso. Profesor en las Universidades de Tarapacá,de Valparaíso y de Chile, jhidalgo@uta.cl

3 Licenciado en Historia, Universidad de Valparaíso. Co-investigador proyecto FONDECYT 1980638.
1775 , período en el que se iniciaba la preparación de la cuaresma. Los gallardetes indicaban la realización del baile del pato, una de las tantas actividades que daban aquel aire festivo y carnavalesco de las fiestas de carnestolendas, fiesta que hacía olvidar, por un momento, a naturales y españoles, las preocupaciones y los ajetreos cotidianos que les demandaban diariamente las labores en el mineral. Sin embargo, las alteraciones propias de los días de carnaval amenazaban con prolongarse más allá del tiempo instituido por la costumbre.

El altercado ocurrido, en ese martes de carnestolendas, entre un comerciante español y un indio provocado por la actitud soberbia de quien se siente dominante en un mundo de castas y jerarquías, pondría al descubierto las profundas y complejas tensiones que, hacía ya tiempo, oponían a naturales y españoles. Estas tensiones habían ido dando forma a una soterrada historia de resistencia, caracterizada por una fuerte oposición étnica frente a los excesos de los corregidores que sobrepasaban los marcos de la "moralidad comunitaria" pero que, también, se veía profundizada por la percepción que los indígenas tenían de la dominación colonial y de sus colonizadores: los españoles viracochas. El tiempo de la revuelta podía, entonces, estallar confundido con el tiempo de carnaval en todo lo que éste tiene de inversión y alternancia.

En este trabajo nuestro propósito es explorar el contexto en el que se inscribe la rebelión de carnestolendas, para lo cual distinguiremos los siguientes niveles de análisis:

a) Articulación (o intensificación) de un proceso de control y dominación coloniales, que tienen su 
expresión en las políticas fiscales desarrolladas por los corregidores de la época: exacciones fiscales, reducción a pueblos, fundación de escuelas, eliminación de modos de expresión culturales, etc. Por una parte, sostenemos que, en su conjunto, estas políticas formarían parte de un proyecto hegemónico destinado a controlar a los grupos subalternos. Pero, por otra parte, ese proyecto encontraría ciertos grados de resistencia táctica entre la población indígena. Lo que obliga a explorar, en un segundo nivel, los procesos étnicos que estarían tras esta "resistencia táctica".

b) Procesos de redefinición étnica que permiten comprender a los grupos atacameños como unidades culturalmente distintas e históricamente dinámicas. El acento está puesto en la redefinición, en la invención de tradiciones y en la apropiación de lenguajes coloniales, dejando de lado un enfoque "esencialista" o "comunalista".

c) De los ritmos culturales propiamente étnicos se deriva un tercer nivel constituido por la percepción de la situación colonial y la elaboración de una "economía moral" que fundamente y legitima la rebelión de Ingaguasi. Esta "economía moral" es el resultado (paradójico si se prefiere) de la apropiación de aquellos enunciados coloniales destinados a legitimar el control sobre la población indígena, como, por ejemplo, de aquel que hacía del indio una "persona miserable" y, por tanto, provista de cuidados, privilegios y regalías.

Los hechos que anteceden a la rebelión forman parte de una estrategia étnica tendiente a reafirmar una moralidad comunitaria que se veía amenazada por el accionar de los corregidores y de sus agentes. Por lo que en este análisis utilizaremos un enfoque dinámico y cultural que nos permita entender la revuelta dentro de las dinámicas étnicas, lo que no significa, por otro lado, que consideremos que tales dinámicas se desarrollen independientemente de los procesos coloniales que afectaban a las comunidades indígenas, como son las exacciones fiscales, los procesos reduccionales, la instalación de escuelas indígenas, etc., porque precisamente las formaciones étnicas coloniales derivan de procesos de etnogénesis, desarrollados en el marco colonial (Gade, 1991; Abercrombie, 1991; Hidalgo et al., 1997 Ms.). En esta última perspectiva de análisis recogemos una afirmación de Abercrombie, quien sostiene que los procesos de articulación y dominación coloniales abrieron canales de participación indígenas pero, mediante los cuales, expresaron, en algunas ocasiones, "algo muy parecido a lo que los arquitectos de la colonia habían previsto. Un tipo de resistencia táctica que, en oportunidades, deviene en terreno fértil para la rebelión" (Abercrombie, 1991: 203).

\section{Santa Loreto de Ingaguasi}

En las altas mesetas de la sierra cordillerana (entre los $25^{\circ} 32^{\prime}$ lat. $S$ y $67^{\circ} 00^{\prime}$ long $\mathrm{W}$ ), aprovechando sus placeres de oro, se localizaba el mineral de Santa Loreto de Ingaguasi. Distaba unas cien leguas de San Pedro de Atacama, con el que se encontraba conectado por un camino cuya marcha podía realizarse en once días con buen tiempo, y en veintiún días cuando las intemperies del tiempo la hacian forzosa. Jurisdiccionalmente, Santa Loreto de Ingaguasi formaba parte del anejo de Belén de Susques dependiente del pueblo de Toconao de la provincia de Atacama. ${ }^{4}$

En torno de la explotación minera giró una regular actividad comercial y tributaria, con su corte de mercaderes y cobradores de tributos, junto con un pequeño asentamiento conformado por una plaza, una capilla, casas de cabildo, y unas cuantas construcciones más que albergaban a los comerciantes y sus tiendas, y a los mineros indígenas y españoles. La población del asentamiento fluctuaba entre ciento cincuenta y doscientos indios y medio centenar de españoles. Por el diseño, el asentamiento corresponde a una estructura colonial de pueblo de indios ${ }^{5}$, lo que explica la presencia de estructuras de autoridad indígenas (segunda persona del gobernador, principales, alcaldes y cobradores de tributos), pero bien pudo surgir primariamente como un nucleamiento deriva-

Hemos utilizado la breve descripción de Ingaguasi que realiza Solano Astaburuaga (1899) y la información que se encuentra dispersa en las siguientes fuentes documentales: "Testimonio del expediente en que se comiciono a Don Josef Maria Paniagua para la aberiguacion y pacificacion del tumulto acaesido en la provincia de Atacama en el asiento de Yngaguasi por el año de 1775", Archivo General de la Nación Argentina, Interior, legajo 6, expediente 8 (en adelante AGNA, Interior, leg. 6, exp. 8); "Testimonio de los autos criminales seguido de oficio de la Real Jus- 


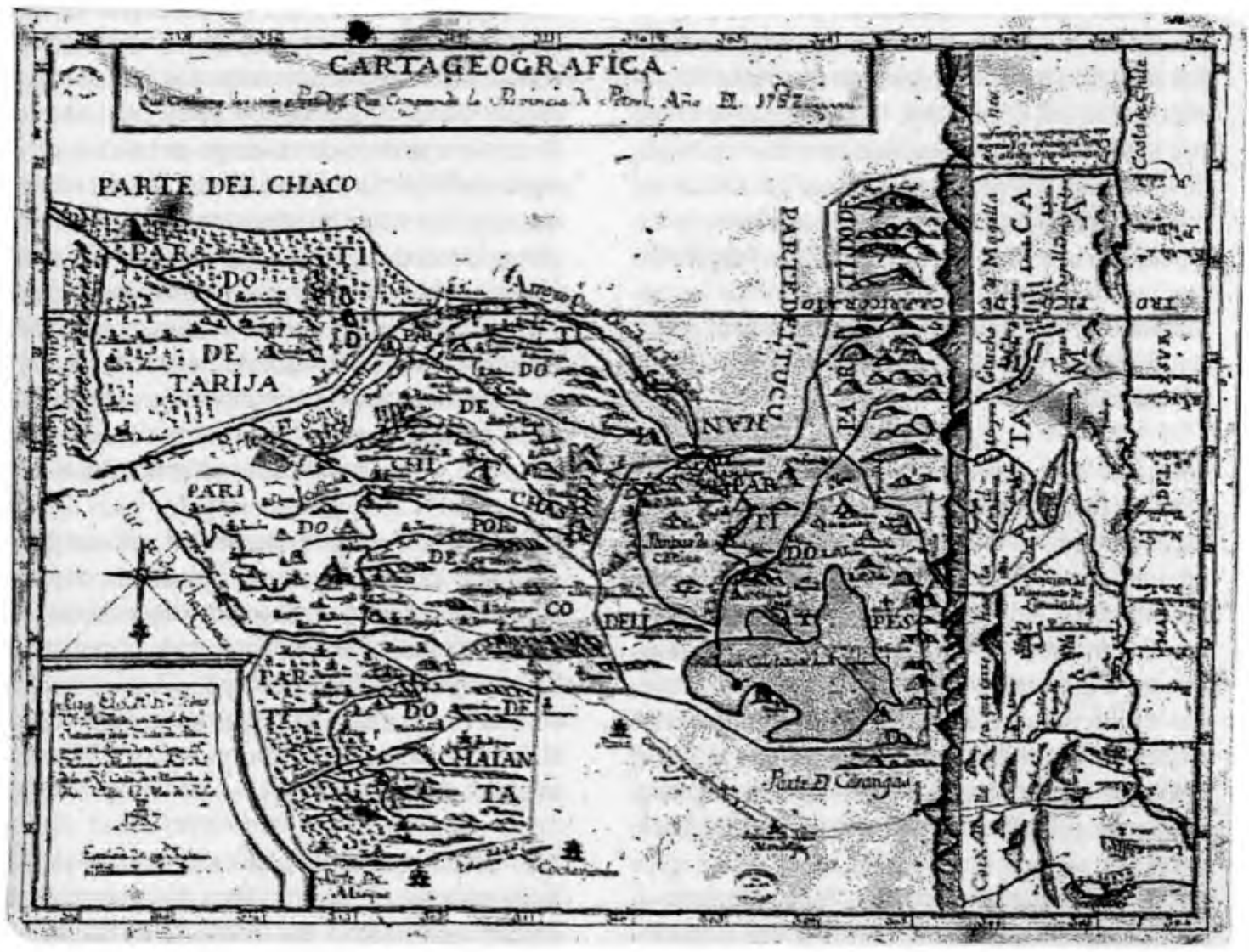

Figura 1: "Carta geográfica que contiene los seis partidos que comprende la Provincia de Potosí, año de 1787“. Catálogo de Mapas y Planos, Buenos Aires, Archivo general de Indias, Tomo I, $N^{\circ} 160$

do de la actividad minera. ${ }^{6}$ En tanto estructura colonial, la disposición del asentamiento ayudaba a crear una atmósfera pueblerina en la sierra, extendiendo, de este modo, el vivir en policía (política y cristiana), en una palabra, la civilización. Esto último se convertirá, tras la revuelta de carnestolenda, en una de las mayores preocupaciones del poder político local.
La actividad comercial pareció estar abocada a un intercambio de mercaderías por oro, pero en un porcentaje menor, por cuanto los indígenas requerían el oro para el pago de tributos. De ahí que los cobradores de tributos indígenas hayan podido concentrar la mayor parte de la producción indígena para el pago de las obligaciones fiscales. El quinto real era cobrado por un agente del corregi- ticia en la provincia de Atacama por el Theniente de Capitan General Corregidor de ella don Josef María Paniagua", Archivo General de la Nación Argentina, Criminales, legajo 10, $\mathrm{N}^{\circ} 3$ (en adelante AGNA, Criminales, leg. $10, \mathrm{~N}^{\circ} 3$ ).

5 Las propias Leyes de Indias ordenaban que "haziendo eleccion de sitios acomodados, y sanos, hagan, y funden poblaciones de indios, donde se recojan, y vivan en Pueblos formados, y tengan la Doctrina, Hospitales, y todo lo demas necessario, en que sean curados los enfermos, y acuda con mas voluntad, por el inte- rés, que resultara de su trabajo, con que será necessario tener otros por repartimientos de mas lexos. Y por que el beneficio, y conservacion de las minas es tanta importancia, que por ningun caso se debe disminuir, y conviene, que siempre vaya en aumento" (Recopilación de las Leyes de Indias, Tomo II, Libro VI, Título III, Ley X).

6 Para una tipología de los asentamientos atacameños contemporáneos remitimos a Castro y Martínez (1996). 
dor, quien residía en el mineral, pero los propios principales atacameños no sabían si aquél era juez a prevención o de comisión, pues cobraba las dependencias del corregidor, "y rescatandole el oro con sus efectos interesandose en todos sus negocios". 7 Tanto los principales como los indios del común, debieron haber visto con molestia la actuación de este juez y la del resto de los españoles que residían en el mineral, especialmente los comerciantes, como para haber sido el objeto predilecto de los ataques durante la revuelta de carnestolenda.

Ante este excesivo control de la producción minera, las autoridades étnicas atacameñas debieron haber pensado en una alternativa que les fuera más favorable, tal vez, otro intermediario. Más aún si los indígenas entregaban la producción en bruto, con la consiguiente baja en el valor del producto minero a la hora de intercambiarlo por mercaderías o entregarlo como pago por los tributos, ellos requerían que se les diera un mejor precio por el oro o que pudieran contar con la tecnología necesaria para procesarlo. El potencial intermediario debía ser alguien que pudiera hacer frente a los poderosos intereses locales y, especialmente, al control que el corregidor ejercía sobre la actividad minera. En períodos anteriores, como es el caso del corregidor Manuel Fernández Valdivieso hacia la década de 1750 , el corregidor había incluso expropiado propiedades mineras al punto de ejercer un abusivo control sobre los indígenas y sus actividades productivas, llegando a acaparar, mediante la fijación de precios irrisorios, gran cantidad de productos como medio de pago de los repartos (Cf. Hidalgo y Castro 1997: 125-129).

\section{El cura y sus fieles}

La atareada actividad doctrinal que desplegaba por los pueblos, parajes, quebradas y sierras de la provincia de Atacama, colocaba, al cura Miguel de Olmedo, en contacto con las almas de su feligresía. Fue en tales travesías que el cura logró establecer una fuerte relación con las autoridades indígenas y con el común de indios al punto de conciliar sus intereses. No debió ser para el cura una tarea exenta de dificultades, pues debía romper con los propios temores de los indígenas quienes se habían acostumbrado a las alianzas y complicidades de curas y corregidores de épocas anteriores
(Cf. Hidalgo y Castro 1997: 130). En lo inmediato, tales intereses provenían de las constricciones económicas que mutuamente los aquejaban. El escaso atractivo económico que significaba para el cura el ejercicio de su cargo en una región caracterizada por la miseria de sus gentes, cuestión que también había preocupado desde antes a los corregidores de la provincia, y la poca o casi nula oportunidad que tenía para obtener ingresos por vía de capellanías u otros medios considerados legítimos, bien pudo haberle llevado a centrar su atención en la actividad minera que se desarrollaba en las altas mesetas de la sierra cordillerana, y en la que, en todo caso, los indígenas estaban expuestos a los abusos del corregidor y sus agentes. El cura instaló en Los Chorrillos ${ }^{8}$, un paraje cercano al asentamiento de Ingaguasi, dos trapiches para moler el oro que obtenía de los mineros indígenas. Lo que sucesivamente atrajo la molestia de los corregidores Argumaniz y Paniagua, menos en consideración a la ilegitimidad de tal actividad que al daño provocado a sus propios intereses económicos.

Aun cuando las actividades económicas estaban terminantemente prohibidas a los eclesiásticos, porque significaban una ofensa a la pureza que debía reinar en la casa de Dios y sus ministros, los clérigos desarrollaban algún tipo de actividad para proveerse de ingresos, aparte de los derivados de su propia actividad como los censos y las capellanías. El desarrollo de actividades económicas, como las derivadas de minas, ingenios y trapiches, debió haber estado lo suficientemente extendida entre el clero, que había burlado la prohibición del Concilio Limense de 1583 que les impedía este tipo de negocios, utilizando para este propósito a terceras personas. Por lo que el Sexto Concilio Limense de 1772, estableció, en la Acción III, título I, que versaba sobre la vida y ho-

"Escrito desde la cárcel de los indios Alejo Ventura,
indio principal y segunda persona de Gobernador del
asiento y mineral, y Diego Martín Siaris, indio prin-
cipal del mineral", AGNA, Interior, Leg. 6, Exp. 8,
foja 15 r.
Chorrillos podría indicar un tipo de obraje minero de
menor tamaño. El nombre del paraje indica que el
área era un centro de elaboración o refinamiento de
metales, aunque en pequeña escala. Sería interesante
una verificación arqueológica de esta información.


nestidad del clero, que "los prelados no permitan a clerigo alguno por ser cosa indecente a su estado y que podria causar mal ejemplo [...]" tener "injenios y trapiches, y en su conformidad se manda que todos los clerigos se abstengan de lo expresado sin trabajar minas tener trapiches y ingenios ni por si ni por interposita persona" (Vargas, 1952: 72). Los clérigos que se arriesgasen a contravenir esta disposición del Concilio quedarían expuestos a penas que iban desde una excomunión mayor hasta penas pecuniarias (doscientos pesos por la primera ocasión, cuatrocientos pesos por la segunda y la confiscación de minas y trapiches si incurriera en una tercera).

Fuertes motivos tuvo que tener el cura de San Pedro para contravenir las disposiciones conciliares. Más arriba hemos supuesto que los escasos ingresos generados por el beneficio de San Pedro, impulsó, al cura Miguel de Olmedo, a dedicarse a la explotación minera. Para todo postulante al sacerdocio, la carrera eclesiástica era una relativamente interesante y segura fuente de ingresos, además de los privilegios que se obtenían, como el de los fueros eclesiásticos. El acceso mismo al sacerdocio estaba restringido para una gran cantidad de personas, dadas las exigencias económicas y educacionales. La posesión de una congrua (ingreso de por vida), que equivalía a unos doscientos pesos anuales de la época, debía ser probada ya sea por la vía de obtención de algún beneficio eclesiástico, cuyas probabilidades eran escasas, o por el hecho de pertenecer a alguna familia acomodada. Esto podía ser suplido con las capacidades intelectuales del futuro sacerdote, como es el caso de don Miguel de Olmedo quien era doctor. Pero no pudo haber obtenido tal grado sino hubiera podido financiar sus estudios, por lo que es posible suponer que perteneciera a una familia relativamente acomodada.

En tanto doctor, el cura Miguel de OImedo se escapa del modelo colonial propuesto por Ganster, según el cual los sacerdotes de mayor nivel educacional se concentraban en las principales ciudades de los virreinatos, dado que éstas eran más propicias para vivir y trabajar, y los de menor preparación se recluían en las provincias y zonas rurales (Ganster 1993: 151) ¿Qué hacía entonces el doctor don Miguel de Olmedo en una provincia tan marginal respecto de los grandes centros eco- nómicos y administrativos de la colonia, limitando sus propias expectativas económicas? Lo que no considera el modelo de Ganster es que, aun cuando las provincias marginales eran poco propicias para vivir y trabajar, estaban lo suficientemente alejadas de la mirada de las autoridades eclesiásticas como para desarrollar actividades prohibidas a los clérigos.

Es un hecho que don Miguel de Olmedo construyó, en el mineral de Ingaguasi, dos trapiches para moler minerales, que le debieron reportar una buena cantidad de oro que paliaban sus desmejorados ingresos. Sin embargo, pensamos que bien pudo responder esto a algo más que a las motivaciones económicas. Es posible que su actuación estuviera motivada por prestar ayuda a los indígenas frente al injusto proceder de los corregidores, y así fue como aquéllos lo percibieron como para negarse a pagar los tributos al corregidor. De acuerdo a esto, el comportamiento de don Miguel de Olmedo puede inscribirse dentro de aquella tradición eclesiástica que hacía equivalente la justicia con los principios del cristianismo. ${ }^{9}$

Lamentablemente, carecemos de una mayor documentación para explorar estas cuestiones, pero sí para afirmar que entre el cura y los líderes indígenas hubo una profunda vinculación de la cual las actividades económicas eran un aspecto circunstancial.

Para los indígenas, como lo veremos más adelante, el cura fue un gran aliado no sólo para elaborar las tácticas de resistencia ante los corregidores, sino que, muy probablemente, para unificar los criterios entre las propias autoridades indígenas y los distintos segmentos de las comunidades, superando, de esta forma, la fuerte dependencia que la autoridad étnica atacameña había tenido de las estructuras políticas hispánicas (Hidalgo y Castro 1997: 31).

Lo que resulta un anacronismo, pero si consideramos que, años más tarde, durante la rebelión de Tupac Amaru, se encuentra un discurso religioso que ligaba la fe cristiana con la lucha por la justicia social (Klaiber 1982). 


\section{Las subordinaciones coloniales}

Varias disposiciones reales habían insistido en la necesidad de separar los asuntos y competencias de curas y corregidores. En épocas anteriores, y en otras zonas del virreinato, sacerdotes habían encabezado levantamientos indígenas contra los corregidores. El Sexto Concilio Limense había vuelto a insistir también sobre esta cuestión. Las predicas debían procurar instruir a los fieles en la subordinación ante los poderes reales, la observación de las leyes reales y enfatizar:

radicalmente en que estos actos de veneración y respecto no son devidos al soberano por una mera razon politica o en fuerza de un temor servil a su justicia sino en virtud de la Obligación estredrísima que en conciencia tienen de sujetarse a las lexitimas potestades dimanadas de las Leyes Divina y humana (Vargas 1952: 25).

La acción de no pagar los tributos al corregidor, aconsejada por el cura, de manera de utilizarlo para costear un pleito en su contra ante la Real Audiencia, rompía con las subordinaciones y respetos debidos a los representantes locales de la autoridad real. El corregidor Francisco de Argumaniz, informando a la Real Audiencia sobre los sucesos de Ingaguasi, acusó a los indios de San Pedro de haber robado cincuenta onzas de oro:

sujeridos de otras perzonas que debieron en cumplimiento de sus empleos propender, a la paz, y quietud de las repúblicas en aquella jurisdicción, y que por esta razon se hallaban sus naturales, aliados, y amotinados con el artificioso disfras contra la Real Justicia que en nombre de su Magestad (Dios le Guarde) ejerse el Corregidor, sin poderla administrar con la amplitud que se requiere. ${ }^{10}$

La existencia de una república de indios, estructurada tempranamente por las disposiciones reales, no perseguía por objeto la creación de espacios de autonomía étnica sino la instalación de espacios que delimitaran la casta de naturales dentro de un sistema de jerarquías y subordinaciones que reproducía un orden divino. Cuestión esta última qué había sido reafirmada por la disposición del Concilio que hemos citado más arriba. En este ordenamiento piramidal, las jerarquías y subordinaciones excluían las alianzas, las que alentaban y conducían al amotinamiento. De ahí que la alianza entre los naturales perturbara la paz, rompiendo las jerarquías incitara al desorden, e impidiera la circulación de la justicia --es decir, del poder -- que el corregidor ejercía en nombre de su Majestad.

\section{Del carnaval a la cuaresma}

El carnestolendas ${ }^{11}$ de 1775 habría sido, como en años anteriores, otra de aquellas fiestas que se intercalaban en el solemne y recargado calendario religioso colonial. No era, eso sí, una festividad propiamente religiosa ${ }^{12}$, incluso fue objeto de críticas y censuras por parte de una Iglesia dispuesta a recuperar el imaginario de los grupos subalternos, que hasta aquí se habían sustraído al control
"Informe del Corregidor Argumanis..." AGNA, Interior, Leg. 6, Exp. 8, fojas $2 r$ - $v$.

11

Etimológicamente, carnestolendas es una antigua denominación castellana derivada de carne y tollere 'quitar', correspondiente al italiano levare 'quitar', asociados al latín carniprivium, 'privar de came'. Pero esta etimología no nos permite precisar la asociación del carnestolendas con la inversión y lo festivo, pues el 'privarse de carne' formaba parte de las actividades de cuaresma. No obstante, la asociación puede realizarse si consideramos que carnestolendas éra una de las denominaciones castellanas para carnaval, las otras dos eran antruejo y carnal. La vieja expresión castellana antruejo es una alteración de entroido, derivada de introitus, 'entrada' de cuaresma. En portu- gués, el verbo antruejar se traduce como 'dirigir pullas carnavalescas', 'motejar', 'divertirse en carnaval', 'causar engaños inocentes como en carnaval'. Antruejada, 'broma grotesca', entrejúa 'cencerrada' señalaría este aire festivo asociado a! carnaval (Cf. Corominas 1954).

12 No aparece entre las festividades religiosas establecidas por el Concilio Limense.

13 Sobre el problema del control hegemónico de los imaginarios subalternos, consúltese Ginsburg (1997).

14 Entre los siglos XIV y XVIII el control de los grupos hegemónicos se extiende hacia a aquellas expresiones rituales que señalaban el reconocimiento de un individuo por parte de la comunidad, o, si se prefiere, 
hegemónico. ${ }^{3}$ En la Europa medieval y renacentista, el carnaval formaba parte de una cultura popular cuya concepción cómica e invertida del cosmos se oponía al ordenamiento socio-cultural de las clases hegemónicas (Bajtin 1989). En el carnaval, como en otras fiestas de contenido similar, era evidente el desprecio hacia Dios, los oficios divinos, las dignidades eclesiásticas y reales, por lo cual, desde fines de la Edad Media, estas prácticas conocieron una fuerte represión y supresión, que se vieron acrecentadas tras el proceso de contrarreforma iniciado por el concilio de Trento (Mandrou 1962: 140)..$^{14}$

El carnestolendas comprendía el conjunto de actividades desarrolladas durante los tres días que antecedían el inicio de la cuaresma. Acostumbrados hoy a una representación 'pagana' del carnaval, nos es difícil vincularlo con una temporalidad profusamente sagrada. El tiempo de la cuaresma era un proceso ritual de purificación por el que pasaban los antiguos paganos, los catecúmenos, para completar su conversión. Los días de carnaval, el tiempo carnal, ritualmente equivalía a la restitución del 'paganismo', de una carnalidad (festejos, bailes, mascaradas, comidas, en una palabra, excesos) que se oponía a la espiritualidad (ayunos, maceraciones, oraciones, etc.) de la cuaresma (Cf. Le Roy Ladurie 1989: 116-117). ${ }^{15}$

Para colocar en su real dimensión el tiempo de redención y purificación que le estaba asignado a la cuaresma hemos de considerar un episodio que, aunque no se inscribe en los acontecimientos que analizamos, por lo menos permite una caracterización de la cuaresma. Dentro de las tácticas de sometimientos de los grupos atacameños que se rebelaron en 1781 , el cura de Chiuchiu "dispuso los Viernes de Quaresma una hora de disiplina por las noches y el Miercoles Jueves y Viernes dc la semana Santa", durante la noche del viernes santo el propio cura ingresó a la iglesia vestido con "un saco Zeniciento, descalzo de Pie y Piernas puesto un par de grillo con contrapeso de dos barretas de fierro en las extremidades de los Grillos con una cruz pesada al ombro y una corona de espinas en su caveza". Esta escena despertó "la gritería llantos y zollosos que a su imitación muchos Yndios se desnudaron publicamente y empesaron a castigarse y las mugeres mui compungidas, no sesavan de darse golpes en la cara por espacio de ora y media qué duro su sermon" (Hidalgo, 1981: 223). El drama, puesto en escena por el sacerdote, fue capaz de interpelar a los indígenas, resituándolos en el espacio que la rebelión pretendía quebrar, el de un ordenamiento colonial inspirado divinamente.

En las colonias españolas de América, junto con las solemnidades de las festividades religiosas se introdujo también la celebración del carnestolendas. Desconocemos las dimensiones que éste tuvo en el interior de los grupos étnicos. Por una hipótesis retrospectiva, podemos suponer que se inscribió en las dinámicas étnicas ya en épocas coloniales. De acuerdo a van Kessel, los grupos aynaras contemporáneos incorporaron el carnaval dentro de sus propios "ritos de producción". 16 la manera en que la comunidad ejercía un control social sobre los individuns. Aun cuando cstos rituales fueron ccnsurados porque alteraban el buen orden y la decencia, cl rechazo y la denuncia que hicieron los individuos que sufrían las consecuencias de una cencerradi o una asoude expresa la irrupción de un ámbito privado que se opone sistemáticamente a la costumbre (Cf. Fabre 1992).

15 Para un mayor conocimicnto del carnaval seguirí siendo insustituible la consulta del texto de Caro Barojá, del cual cl texto citado es una recensión.

16 Entrc los actuales aymaras, señala van Kessel, el carnaval se inscribe entre los ritos de producción destinados a provocar un año abundante en la producción igrícula 0 ganadera. "I as fiestas de Camaval dan comicnzo a la época de la cosecha. Son una alegre acción de gracias y a la vez una primera evaluación ritualizada. Los agricultores dan gracias a la Pachamama por las primicias de frutas, papas y choclos qué se exponen con orgullo. Es liesta de alcgría, encabczada por un personaje alegórico, el "Tío Carnaval", que llega al pueblo en un burro y que se retira al término de la fiesta. Hay cantos alusivos c improvisados con rondas de baile" (van Kessel 1996: 61). En Guañacagua. valie de Codpa, cl personaje alegórico se le denomina "Carnavalón" y se le describe en una relación de parentesco pasado: el abuelo con relación a la comunidad actual. 
Sin embargo, en obras como la Nueva Coronica y Buen Gobierno de Wamán Poma de Ayala se manipularon ciertas representaciones del carnaval para expresarse ante el rey en un lenguaje y figuras que le fueran más familiares, de manera de enfatizar el caos que se vivía en las colonias del virreinato (Cf. Randall 1993). Tal era la idea de "mundo al revés" cuya presencia en la obra de Wamán Poma se ha asociado tradicionalmente al concepto de pachakuti. No obstante, de acuerdo a Randall, lo que hizo el cronista indígena fue manipular no tanto un concepto andino como una representación del "mundo al revés" asociado al carnaval, retomando, de este modo, una perspectiva negativa del carnaval, propia de la Iglesia de la Contrarreforma. Las metáforas del carnaval podian llamar fuertemente la atención en las cortes, a diferencia de las representaciones andinas, como las derivadas del pachakuti, con mayor audiencia en un público aborigen.

Es este lenguaje del carnaval el que aquí nos interesa resaltar. Estructuralmente estas festividades podrían asemejarse a los rituales de rebelión estudiados, en otras latitudes, por antropólogos. Pero, como hemos señalado más arriba, los contenidos asignados al carnestolendas no nos permiten avanzar en esta dirección, arriesgándonos a una comparación empobrecedora. Entre estas expresiones, la de inversión del orden, sin embargo, podría mantenerse. Pero esta inversión no deriva de una funcionalidad estructural que tiende a la reducción del conflicto, resolviéndola de manera ritual. La fiesta podía asumir eso sí una dimensión no deseada por los grupos hegemónicos. Esta no estaba ligada tanto a las prácticas y excesos, que podían muy bien tolerarse, como a los actos que podrían derivarse de aquellos prolongando, más allá de lo establecido, el "desorden" y el "caos".

Esta última cuestión podía plantearse a propósito de algunos componentes del cuerpo social, cuya debilidad los hacía propensos al influjo de las alteraciones del "ánimo" provocado por los excesos de los días de fiesta. Era el caso de los indios, cuya "natural rudeza y simplicidad" había justificado la instalación de una serie de dispositivos de vigilancia, prevención y corrección. Tales dispositivos debían extremar el control en los días de fiesta y regocijo, no sólo porque el alma quedaba expuesta a los excesos irrumpiendo sus debilida- des, sino que, a partir del mismo movimiento, podía ser arrastrada a una confabulación que en un recto juicio habría prontamente rechazado. Un fallido intento de rebelión, registrado en la propia capital del virreinato del Perú hacia la segunda mitad del siglo XVIII, había precipitado este tipo de vigilancias. De acuerdo a la Memoria del saliente Virrey José Antonio Manso de Velasco, los "regocijos y festividades", en los que los indios habían estado expuestos a la "embriaguez", habían sido los lugares de la "maquinación" y el reclutamiento de confabuladores, en otras palabras la instancia de la rebelión:

\section{Pero tengo por preciso que se observen con disimulo, como lo he practicado por me- dio de ministros de cordura, y mas los dias de regocijos y festividades que estan muy expuestos á la embriaguez y juntas, pues en las que tubieron por espacio de dos años en diversos y retirados sitios, alentaron su maquinacion y le aumentaron su.s cómpli- ces (Memorias, t. 4, 1856: 98)}

Las fiestas y regocijos, provocaban, para la cultura dominante, una "exaltación traducida en gritos y gestos, cantos y danzas, que suele acabar en orgía y violencia" (Mandrou 1964: 138), transformándose, como el carnaval, en "soporte continuo de expresiones de inversión y de lenguajes subversivos" (Vovelle, 1981: 191). El carnaval como soporte de un lenguaje y actos subversivos, pero cuya instancia de producción se haya subdeterminada por una situación concreta de explotación y dominación coloniales, $y$, de otra parte, por un proceso de apropiación de sus contenidos por parte de los grupos indígenas.

\section{La rebelión de carnestolendas de 1775}

El último domingo del mes de febrero de 1775 , volvió a congregar, en el asiento, a los indígenas que laboraban en el mineral de Ingaguasi. Era el primer día del carnestolendas que se prolongaría hasta el martes, pues el miércoles de cenizas se daría inicio a la cuaresma. Por unos días, los regocijos y diversiones, romperían con el ritmo habitual de las obligaciones laborales. Sin que aconteciese ninguna historia, transcurrieron los dos primeros días de carnaval. 
Como en otras ocasiones, al igual que los demás naturales, Alejo Ventura, indio principal del asiento, se dirigió, en la mañana del martes, a comprar una solapa en la tienda del mercader de géneros Domingo Chávez. Molesto, tal vez, por los términos del intercambio ofrecido por el comerciante, "tubo la osadía de tirarsela a la cara al tal Chavez". ${ }^{17}$ El mercader echó de su tienda al joven atacameño ante la mirada de los demás naturales que se hallaban circundantes y dispersos. Unos españoles que se encontraban en el lugar le dijeron a Alejo Ventura "que se dibiertiese, y sosegasen, sin que resultase ninguna historia, a que respondio el tal Alejo que no abria nada." I8 No fue de la misma opinión el principal Diego Siaris; increpando a los propios españoles les dijo que "ellos tenian la culpa." ${ }^{19}$ Un minero llamado Antonio Contreras sacó un cuchillo e hirió en el brazo de dos puñaladas a Diego Siaris, sin entender, algunos de los españoles, "las rasones que dicho Contreras le desia al yndio, y asi no pudo enterarse del motibo o probocacion con este enardecio el caso como para que lo hubiese herido." ${ }^{\prime \prime}$ En el instante, los demás indios que hasta aquí se habían limitado a observar, permaneciendo unos junto a la capilla y otros en una casa vecina, corrieron hasta la casa del mercader rodeándola. Recogieron de la calle grandes piedras que arrojaron con fuerza a la puerta de la casa, que los españoles habían cerrado para evitar el ataque de los naturales. Otro grupo de naturales comenzó a destechar la casa ante lo cual los españoles entreabrieron la puerta:

hasiendo campo con algunas bocas de fuego de que salio un yndio lastimado para poder salir afuera huyendo, como lo lograron; pero apenas salieron quando los yndios maltraron a pedradas y siguiendo a don Juan Bautista Miner, y a don Domingo Chaves, se refugio este en una casa, donde cercandolo la muchedumbre de Yndios, oyo el declarante que dijeron todos peguenle fuego, para que no se escape. ${ }^{21}$

A su manera, los atacameños hacían de Miner y Chávez, el cobrador de impuestos y el mercader, objetos de "cencerradas", pero de una broma en la que sus propias vidas corrían el riesgo de fenecer. Ante estas escenas, las risas y carcajadas de carnaval daban paso a un rictus espantoso que era acentuado por el riesgo de muerte que "amenasaba a todos los españoles" (Ibid). Para escapar a tan inminente peligro, algunos españoles se escondieron en las minas y parajes cercanos al asiento minero. Miner mismo, junto a otro minero, huyeron a pie del mineral. No corrió la misma suerte el mercader Domingo Chávez, a quien los indios habían perseguido al salir de su casa, lo "maltrataron dandole con piedras grandes en la cabeza y la cara, y de esta forma casi muriendo, lo amarraron y llebaron preso, al paraje que llaman el Agua Salada." ${ }^{22}$ La descripción de otro testigo español alcanza ribetes más dramáticos. $\mathrm{Al}$ momento de ser capturado, Chávez venía huyendo de los indios que lo querían quemar:

$y$ de tanta sangre como bertia, y una pedrada que le tiro uno de tantos yndios que le seguian caio en el suelo como muerto, y se le aserco un yndio con una piedra grande a darle en la cabeza; para acabarlo de matary don Pedro Hidalgo que estaba junto al que declara, le dio un grito al Yndio, con lo que el, no le acabo de quitar la vida. ${ }^{23}$

Ante estos hechos, un español que hasta aquí había sido testigo de los acontecimientos y que se había librado de los ataques de los naturales, trató de buscar algún objeto que interpelara y que actuara más fuertemente sobre la conciencia religiosa de los indios, de manera de "apaciguar el tumulto.” Se dirigió a la capilla de la Iglesia y sacó del altar la imagen de Nuestra Señora de Loreto, llevándola al lugar de los acontecimientos. Una inesperada respuesta recibió de los atacameños, "diciendole todos se quitase con la Virgen, porque con Virgen y todo hauianle haser lo mismo con el; le quitaron al declarante la ymagen." ${ }^{24}$ No

\footnotetext{
17 Declaráción de Antonio Bórquez", AGNA, Interior, Leg. 6, Exp. 8, foja 30r. Ibid. Ibid. "Declaración de don Jorge Pirola" AGNA, Interior, Leg. 6, Exp. 8, foja 27v. AGNA, interior, Leg. 6, Exp. 8, foja 28r. AGNA, Leg. 6, Exp. 8, foja 28r-v. "Declaración de don Antonio Bórquez", AGNA, Leg. 6, Exp. 8, foja 30v-3」r. Ibid. foja 31 r.
} 
era de extrañar una tal actitud por parte de los indios, este rechazo bien podía expresar no un rechazo de la ritualidad religiosa sino que al monopolio que los españoles tenían sobre tal universo ritual. Careciendo de mayor información documental, la afirmación anterior es un tanto arriesgada. En su declaración, el testigo explícitamente sostiene que la imagen correría su misma suerte si él no se retiraba. Esto último supondría, en otra perspectiva de análisis, un rechazo de la totalidad del universo sagrado, en la medida que este universo era la expresión de un esquema de dominación colonial. Sin embargo, al insistir el testigo en el rechazo que los indios hicieron de la imagen, estaba reforzando, como lo veremos más adelante, la 'gentilidad' y 'barbarie' de los indios sostenidas por los corregidores. El hecho, que tiende a afirmar nuestra conjetura, es que los indios no destruyeron la imagen sino que tan solo se la quitaron al español. Después de todo, estaba de su parte la máxima autoridad espiritual y religiosa de la provincia de Atacama.

La actitud de los indios podía obedecer, de otra parte, a la dinámica que iban adquiriendo los acontecimientos. Al abrirse campo con bocas de fuego, los españoles habían herido a uno de los tantos indios que asediaban la casa del mercader. Al ver peligrar la vida de uno de los suyos, los sentimientos de rechazo hacia los españoles no hicieron más que crecer, "expresaron todos los Yndios, que si el Yndio herido moría hauian de matar luego al dicho Chaves" que permanecía en su poder ${ }^{25}$ Pero ¿se puede entender la actitud de los naturales circunscribiéndola tan sólo a los sentimientos que los acontecimientos suscitaban entre ellos? ¿Era su actitud la de unos individuos debilitados por los excesos de aquellos días de regocijo y embriaguez?

Semanas antes de carnestolendas, habían circulado, entre los indios del mineral, varias noticias proporcionadas por chasquis que trabajaban para el corregidor. ${ }^{26}$ De acuerdo a estas noticias, cl corregidor Francisco Argumaniz había mandado llamar a Juan Bautista Miner y a otros españoles, inquiriendo con qué armas contaba cada uno, señalándoles que estuvieran prevenidos para çuando él los convocase, pues tenía que practicar ciertas diligencias en Ingaguasi. ${ }^{27}$ Estos preparativos comenzaron a inquietar a los indígenas que vi vían en el mineral. La carta remitida por el corregidor Argumaniz el 15 de febrero de 1775 fue vista como una abierta provocación, más aún si los preparativos se realizaban de manera tan secreta ${ }^{28}$ y si el propósito era capturar a algunos principales indígenas que se habían negado a pagar los tributos debidos al corregidor. Miner y Chávez eran los encargados de coordinar los preparativos y, al parecer, el corregidor en una segunda carta les había dado orden de arrestar a los principales Alejo Ventura y Diego Martín Siaris. ${ }^{29}$

Con estos rumores circulando por el mineral, no era difícil augurar un carnaval más tenso y ruidoso que el de años anteriores. El transcurso de los días y semanas que antecedieron al carnestolendas no fue tampoco del todo apacible. Para los indígenas, en cualquier momento podían irrumpir, en el mineral o en el asiento, los viracochas que secretamente se habían alistado bajo las ordenes de Mincr y Chávez. Había pues que extremar la vigilancia, observando con detenimiento las actuaciones de los españoles, principalmente de aquellos que hacían de cabeza y en los que, en todo caso, recaía el cumplimiento de las órdenes dadas por el corregidor Argumaniz. El correr de los días no hizo más que aumentar la incertidumbre. Con la expectativa de días aciagos, llegó el tiempo del carnaval...

El mercader Domingo Chávez colocó, encima de su puerta, un gallardete colorado de sargal, "como es costumbres en barias partes tales dias de carnabal, para serciorar a todos que ay baile o corrida de pato." ${ }^{310}$ Por vez primera, el gallardete colorado fue una señal equívoca que acrecentó las confusiones del momento. Los indígenas vieron en el gallardete una señal destinada a convocar a los hombres que secretamente habían reunido

\footnotetext{
25 Ibid.

26 Ibid., foja $29 \mathrm{v}$.

27 "Declaración de Jorge Pirola" AGNA, interior. Leg. 6, Exp. 8, foja 29r.

28 "Escrito desde la cárecl de los indios principales Alejo Ventura y Diego Siaris" AGNA, interior, Leg. 6 , Exp. 8, foja $15 \mathrm{r}$.

29 "Declaración de don Jorge Pirola" AGNA, interior, Lcg. 6. Exp. 8, foja 28v.

30 "Declaración de Antonio Borque" AGNA, interior, Leg. 6, Exp. 8, foja 29v.
} 
Chávez y Miner. Esta sospecha, de acuerdo a un testigo español, fue la que motivó "la probocación, y tumulto que dichos yndios emprehendieron." 3 Esta situación debió estar presente en aquel martes de carnestolendas cuando el principal Alejo Ventura se dirigió a la tienda del mercader Chávez. Entre otros, sobre aquél también pesaba el arresto ordenado por el corregidor Argumaniz. Pero había otra circunstancia. En una tercera carta enviada por el Corregidor a Miner, cuyo contenido debieron haber conocido también los indios, se había ordenado a éste "registrase a Alejo Ventura, por si le podía hallar alguna carta o papel del cura de Atacama." 32 Si Alejo Ventura arrojó a Chávez el género que le había comprado esta actitud era culpa de los españoles, pues eran ellos los que estaban preparando el alboroto o pendencia contra los indios. ${ }^{33}$

Luego del asedio e intento de destrucción de la casa de Chávez, así como la persecución de los españoles que allí se habían refugiado, los acontecimientos siguieron el rumbo de los días de carnaval. Al quedar la puerta de la casa de Chávez destrozada por las grandes piedras que arrojaron los indios, el principal Alejo Ventura solicitó, al mismo español que había sacado de la capilla la imagen de la Virgen, que cuidara la mencionada casa. En ningún momento de los acontecimientos, aparecieron los cincuenta hombres armados cuya presencia temían los naturales. Sin tener los implementos necesarios para contrarrestar.el temido ataque, los indios decidieron abandonar el mineral "llebandose por fuerza al paraje o quebrada que llaman los Ratones a todos los españoles y mugeres que quedaron aquí." 34 Otro testigo, sostuvo que los mineros españoles habían huido del mineral mientras que a las mujeres "las llebaron los yndios a los cerros pricioneras." ${ }^{235} \mathrm{El}$ mineral y asiento de Ingaguasi quedó casi despoblado sino fuera por dos o tres indias viejas que no marcharon hacia la quebrada. ${ }^{36}$

Las noticias sobre la rebelión de carnestolendas no llegaron al Corregidor de Atacama. Dos días después de haber terminado el carnaval en San Pedro, el corregidor Argumaniz emprendió el viaje a Ingaguasi con el propósito de practicar la visita anual de las minas de dicho mineral ${ }^{37}$ y de resolver los problemas pendientes. El 13 de marzo de 1775 , tras once días de viaje, en los que había experimentado "muchos vejamenes, desafíos, amenazas, hostilidades e improperios" 38 por parte de los indios, el corregidor arribó a Ingaguasi observando un cuadro desconcertante, "lo hallo enteramente decierto y despoblado, sin haber tenido a quien preguntar la cauza de ello porque los yndios havian hechado a pedradas a todos los mineros, $y$ españoles que contenía y se remontaron, aquellos a los cerros circumbecinos. ${ }^{.39} \mathrm{El}$ corregidor utilizó todos los medios a su alcance para hacer comparecer a los indios, pero recibió de ellos la desobediencia, la negación de auxilios para regresar a San Pedro y la osadía de intimidarle para que saliera del asiento. ${ }^{40}$ Ante estas circunstancias, y no pudiendo volver a San Pedro, el corregidor siguió el viaje a la provincia del Tucumán. El $1^{\circ} \mathrm{de}$ abril llegó de Calchaquí, jurisdicción de Salta, para solicitar auxilios e iniciar la averiguación de la sublevación.

\section{Rebelión y procesos étnicos}

En su inmediatez, la revuelta de 1775 discurre en la trama urdida por el espacio y el lenguaje del carnaval. Sin embargo, tanto los ataques que perpetraron los indios contra los principales agentes del corregidor como el despoblamiento que hicie-
"Declaración de Jorge Pirola" AGNA, interior, Leg. 6, Exp. 8, foja 28v.
"Escrito..." AGNA, Leg. 6, Exp. 8, foja 15 r.

"Declaración de Jorge Pirola", AGNA, interior, Leg. 6. Exp. 8, foja 28v.

"Declaración de Bernabé Córdoba", AGNA, interior, Leg. 6, Exp. 8, foja 27r.
36 lbid.

37 "Informe del Corregidor Francisco de Argumaniz sobre la rebelión de Ingaguasi", AGNA, interior, Leg. 6. Exp. 8 , foja 2 v.
Ibid., foja $3 r$.

Ibid. 
ron del mineral permiten pensar, por una parte, que no se trata de una reacción arbitraria y espontánea y, por otra, que el carnaval es utilizado como el soporte de un lenguaje subversivo cuyos ritmos e intensidades hay que localizarlos en una estrategia de resistencia indígena contra las presiones del poder político provincial y de sus agentes.

Contra la opinión que la "rebeldía primitiva" se explicaría por la descomposición de las solidaridades de los grupos y sería una mera reacción espasmódica, carente de las categorías mediadoras que le permitan forjar una percepción de y sobre la realidad que los afecta, sostenemos que la resistencia táctica que formulan los atacameños tiene como soporte complejos procesos que distan mucho de ser expresión de grupos desintegrados.

Uno de estos procesos fue la reestructuración que tuvo el propio poder político atacameño. En la década de 1770 , éste asumió una dinámica particular desligándose de la dependencia que había tenido de los corregidores. Y cuyos efectos, las más de las veces, habían sido nefastos, Iransformando a las autoridades étnicas en cajas de resonancia del corregidor y en dóciles agentes de sus intereses. La designación de caciques y principales respondía más a los caprichos del corregidor de turno que a las expectativas de las comunidades étnicas. Infructuosas habían sido las tentativas de algunos principales indígenas y de algunos linajes por vincular las memorias familiares con una representación histórica que, restableciendo una línea genealógica, legitimara sus derechos al cacicazgo con independencia de los deseos de las autoridades españolas.

Un caso notable es la familia Ramos, miembros del ayllo Solo. La documentación disponible permite demostrar que sus antepasados, en diversos períodos (detectables a partir de 1683), habían ejercido el cacicazgo o más bien la gobernación de San Pedro de Atacama. En 1683 el cacique de Solo don Martín Lorenzo aparece como cacique gobernador de San Pedro de Atacama. Posteriormente, Nicolás Ramos, muy probablemente el hijo del cacique Martín Lorenzo que aparece en la revisita de 1683, fue nombrado, por el corregidor, cacique del ayllo Solo y gobernador de San Pedro. Con anterioridad a su designación, el cargo había sido ocupado, sucesivamente, por Pedro Andrés y Martín León. Este último tenía estrechos lazos de parentesco con Nicolás Ramos. ${ }^{41}$

Hacia la década de 1750, Juan Esteban Ramos, hijo de don Nicolás Ramos, cumplió una serie de tareas políticas como pregonero de la visita de 1751, como cobrador de tributos y como cacique del ayllu Solo. Esas funciones lo llevaron a desplazarse por el extenso territorio de la provincia: Toconao, Salta, El Ingenio, etc. En cada una de aquellas funciones contó con el respaldo y la confianza del cacique principal del ayllo Solo y del corregidor Manuel Fernández Valdivieso. ${ }^{42}$ Hay un hecho en el que brevemente debemos reparar. La carrera de Juan Esteban Ramos aparece asociado a dos controvertidos personajes. El corregidor Manuel Fernández Valdivieso fue fuertemente resistido por un importante sector de la comunidad atacameña llegando a entablarle un juicio ante la Real Audiencia. Fernández Valdivieso trató de extirpar a los curanderos atacameños bajo el pretexto de brujerías e impuso un fuerte control sobre la comunidad atacameña. El cacique de Solo, el mestizo Pascual Isidro Sandón, fue acusado por Pedro Sebastián. hijo del cacique Pedro Andrés, de haberle usurpado el cargo de cacique que le correspondía por herencia, y de usufructuar las tierras que legítimamente les pertenecían a él y a sus hermanos. Sus pretensiones fueron desmentidas por el testimonio del hijo del cacique que había sucedido a Pedro Andrés. Este sostuvo que la sucesión al cacicazgo no era por herencia, sino que, desde tiempos inmemoriales, los corregidores habían designado a los caciques. Esto fue suficiente para que la Audiencia reprendiera a Pedro Sebastian y le prohibiera entablar un juicio similar. El testigo era primo de Juan Esteban Ramos cacique del ayllu Solo y cuyo principal era el mestizo Pascual Sandón. Recordemos que Pedro Sebastián había encabezado las acusaciones con-

\footnotetext{
"Representación de Pedro Scbastián, indio casique del pueblo de San pedro de Atacama, sobre que un mestizo, llamado Pascual Sandón, se ha apoderado del cacicasgo y como consecuencia haber sembrado en ticraas de su propiedad", Archivo Nacional Boliviano, Sucre, Catálogo de Tierras e Indios, E 1758, Nº64. foja $12 \mathrm{r}$.
} 
tra el corregidor Fernández Valdivieso, por lo que, en la oposición a sus pretensiones al cacicazgo, se mezcló la animadversión del antiguo corregidor Fernández Valdivieso (Hidalgo y Castro 1997) y el recelo de los Ramos que el cacicazgo pasara a otra familia. Si las pretensiones de Pedro Sebastián hubieran sido confirmadas por la Audiencia, los Ramos no habrían podido alegar, posteriormente, ningún derecho al cacicazgo por vía de sucesión hereditaria. Lo que los obligó, indudablemente, a desarrollar una estrategia que les asegurara, en el largo plazo, la posesión del cacicazgo de Atacama.

No hay testimonio alguno que nos permita reconstruir las tácticas utilizadas en aquella estrategia familiar. Lo que podemos hacer es inferirla de algunos datos dispersos concernientes a la formación que recibieron los hijos de Juan Esteban Ramos. Todo parece indicar que fueron educados bajo criterios hispanos, imponiéndoseles el olvido de su lengua y un buen manejo de los modos hispanos de expresión. Referentes como el honor y la nobleza fueron inscritos dentro de una memoria familiar que trataba de adornarse para hacer frente a familias rivales. La honorabilidad fue asumida como otra fuente del prestigio que los Ramos acumulaban gracias a otras maniobras ${ }^{43}$

Esta habilidad permitió a los Ramos crear la trama de una nueva tradición que nos ha llegado por los testimonios de los últimos miembros de la familia que poseyeron el cacicazgo, quienes, ante apremiantes circunstancias, estuvieron obligados a exponerla ante el riesgo de perder su poder.

Hacia 1769, la muerte de don Juan Esteban Ramos llevó a su primogénito, don Pablo Ramos, a la sucesión del cacicazgo contando con la "exclamacion de todo el Pueblo." Durante cuatro años Pablo Ramos ejerció el cargo de cacique, pero

"Revisita de Atacama de 1751 y 1756 efectuada por el corregidor don Manuel Fernández Valdivieso" AGNA, Leg. 7-71, foja 9r.

Ver nota 56.

"Solicitud de don Pablo Ramos, indio principal, hijo de Juan Esteban Ramos, cacique principal de la nobleza del pueblo de San Pedro de Atacama Ala", Archivo Nacional Boliviano, Sucre, Catálogo de Tieras e Indios, E 1781, No 7, foja lr. (En adelante ANB "impedimentos de acsidentes" lo llevaron a "sobreseer en dicho empleo transfiriendole mi derecho a mi hermano menor Don Agustin Victorio Ramos." ${ }^{44}$ A éste le tocó enfrentar los ataques del corregidor Argumaniz que tenían por propósito, como lo veremos más adelante, socavar el prestigio y el predominio de los Ramos. De ahí entonces que ante los ataques del mencionado corregidor, el cacique Agustín Victorio Ramos se vio obligado a hacer, en un escrito enviado a la Real Audiencia, una brevísima descripción del origen de sus derechos:

digo que respecto de ser notoria mi sendencia, y que esta tiene su origen de Casiquez principales y Governadores conformados; asi por el Superior Gobierno, como por esta Real Audiencia pues es muy sabido que mis abuelos han obtenido el Gobierno por especial conformacion del Ecselentisimo Señor Virrey de estos Reynos, y posteriormente mi lexitimo Padre don Juan Esteban Ramos ${ }^{45}$

La memoria familiar de los Ramos logró manipular la figura del Virrey y la de la Audiencia, en sus relatos ellas permanecieron como los lugares que legitimaban y fundamentaban su derecho a poseer el cacicazgo. Cualquier intento de restarle legitimidad equivalía a cuestionar la fuente de su autoridad, es decir, la de la propia autoridad real. Los orígenes del poder de los Ramos se confundía pues con los orígenes de la dominación colonial: ambos se requieren para su legitimación. No obstante, todo parece ocurrir como si para los Ramos y otros linajes este derecho fuera tan sólo el reconocimiento de un derecho ancestral.

A juzgar por las oposiciones al cacicazgo, originadas tras la renuncia del hermano primogénito del cacique Agustín Ramos, la elite indígena se

\footnotetext{
45 "Don Agustin Pieroso (Don Agustin Victorio Ramos) cacique de San Pedro de Atacama, declara ser injusta su sentencia de casicazgo, pucs su abuclo fue cacique y governador con consentimiento de los Virreyes", Archivo Nacional Boliviano, Sucre, Catálogo de tierras c Indios, E 1774, No 95, foja Ir. (En adelante ANB E 1774 No 95)
} 
había apropiado de la idea de derecho de sangre para legitimar la posesión del cacicazgo, frente a los intentos del corregidor Argumaniz de "sacar a uno de sus parciales amedretando con esto a todos los que por derecho de sangre tenemos que hazer nuestra oposision." ${ }^{\text {"46 }}$ Argumento que, nuevamente, volverá a esgrimir, tras el fallecimiento de su hermano Agustín Ramos, el renunciado primogénito Juan Pablo Ramos, "por ser acreedor de mejor derecho que ninguno de otros principales por sangre noble y otras circunstancias que adornan toda mi familia." 47

No es sólo el "derecho de sangre", que compartían con otras familias, el que presentaban los Ramos para legitimar su derecho al cacicazgo sino que "otras circunstancias que adorna a toda mi familia." Aquí estamos en presencia de esas estrategias familiares, como las que hemos estudiado en Pica y Tacna (Hidalgo 1996 Ms; Castro 1998 $\mathrm{Ms}$ ), tendientes a legitimar las "memorias familiares" vinculándolas con los orígenes del cacicazgo. Don Juan Esteban Ramos no consideró necesario señalar, ante la Audiencia, cuáles eran las circunstancias que adornaban la historia de su familia, probablemente porque éstas no eran del interés del poder regional, pero su sola mención permite sostener que aquéllas estaban lo suficientemente extendidas como para formar parte del saber público que circulaba oralmente entre los naturales.

Los dos momentos en que los Ramos expusieron parte de su memoria familiar tuvieron como contexto las presiones de los corregidores. Hacia 1774, el recientemente nombrado cacique Agustín Ramos se disponía a emprender el viaje que lo llevaría a recorrer cada uno de los lugares en los que se encontraban sus dispersos tributarios, "los mas de los yndios que constituyen mi parcialidad se hallan dispersos en la provincia del Tucuman", ${ }^{48}$ pero fue notificado por el corregidor "por un Auto baxo del apersebimiento de encarselacion, y otras penas no saliese en mis pies, ni en los agenos executando lo mismo con todos los yndios tributarios que estan a mi cargo tomando para este fin el pretesto de la revisita."49 No le fue difícil al cacique inteligenciarse "de la yniqua maxsima que se contenia en aquella extemporanea providencia". Pasada la revisita, volvió a plantear al corregidor su solicitud pero ésta fue nuevamente denegada.

Para el cacique las intenciones del corregidor eran evidentes. Impedido de cobrar los tributos él debería enterarlos de su propio peculio, pero su falta de riquezas le impedirían lograrlo. Con el incumplimiento del pago de tributos, el cacique daba al corregidor un fuerte motivo para fundamentar su destitución y concretar sus esfuerzos por imponer en el gobierno del cacicazgo a "uno de los que el favorese." ${ }^{.50}$

Este intento por destituir al cacique Agustín Ramos se sumaba a otros anteriores que habían afectado a su familia:

el mencionado Corregidor intentando destruir a toda mi familia depuso a mi hermano mayor del Gobierno que interinamente obtenia por fallecimiento de mi finado padre Don Juan Esteban sin mas merito que la enemiga que nos profesa, y despues de este vexamen lo empadrono a dicho mi hermano obligandole a que presisamente pague tributo, y en esta conformidad ha contribuydo este tres años siendo asi que a pedimento de Vuestra Señoria declaro por Su Alteza por Auto de 11 de julio de 1764 que el hijo primogenito del dicho mi Padre como lo es mi hermano no debe pagar tributos en conformidad de las ordenanzas $^{\text {st }}$

Curiosamente, esta descripción de las circunstancias que acompañaron al alejamiento de don $\mathrm{Pa}$ blo Ramos no coincide con las que el propio primogénito de la familia entregó, años más tarde, en un documento al que ya hemos hecho referencia. En el mencionado documento, don Pablo Ramos sostiene haber entregado a su hermano menor la posesión del cacicazgo que había heredado de su padre y con la aclamación de todo el pueblo. La disparidad de opiniones que se entregan se comprende a partir de los propósitos que tenían ambos documentos. El documento de don Agustín

46

47

48

49
ANB, E 1774, No 95, foja Iv. ANB, E 1781, No 7, foja 1v. ANB, E 1774, No 95, foja 1 r. Ibid., foja I $r-1 \mathrm{v}$. Ibid., foja $1 v$. Ibid., foja $2 r$. 
Ramos estaba destinado a denunciar la ostensible hostilidad que el corregidor había mostrado hacia la familia Ramos "sin omitir para esto lo mas perniciosos medios, con raro artificio, y sobrada malicia," "no siendo tolerable el que a costa de mi deshonor consiga dicho corregidor su desproporcionado proyectos." ${ }^{12}$ Las actuaciones del corregidor fueron considerados por el cacique como una afrenta al honor familiar y, precisamente, es este deshonor el que puede llevar a la destrucción de la familia. La imagen del primogénito destituido y reducido a la condición de tributario es parte de una retórica que, en tanto imagen, produce un efecto persuasivo. En el caso del documento presentado por don Pablo Ramos, fechado en 1781, éste tiene por objetivo reclamar para sí el cargo de cacique dejado por su difunto hermano. Como todos los documentos de su tipo, el documento trata de expresar claramente el derecho que le asiste a don Pablo Ramos en su doble condición de heredero, pues lo fue, por derecho, de su padre y, también por derecho, de su hermano menor. Pero también trata de introducir un juicio sobre su anterior desempeño como cacique: "dentre a la subsecion de aquel casicasgo y gobierno, y lo obtuve quatro años y meses desempeñando el cargo (como es publico y notorio en aquella provincia) con toda puresa y aplicación al Real Servicio." ${ }^{53}$ Su controvertida destitución es sacada de modo de no entorpecer sus pretensiones para ocupar el cargo de cacique, deslizando, a renglón seguido, que "por mis lexitimos impedimentos de acsidentes me fue presiso sobreseer en dicho empleo transfiriendole mi derecho a mi hermano." 54 Con estos enunciados el discurso de Pablo Ramos trata de posicionarse y de responder a otros discursos que circulaban en la comunidad y que estaban caracterizados por un juicio negativo respecto de su capacidad para ejercer el cargo. Cuestión que viene a reafirmarse a través del juicio que el corregidor Andrés Estevez emitió, hacia 1781, sobre Pablo Ramos:

no obstante el derecho que alega y haver estado algun corto tiempo en dicho cargo de Governador y Cobrador de los Reales Tributos se me ha informado por sujeto de verdad que nunca a podido cumplir con su obligacion por ser sujeto destituido de bienes y dejado de la aplicación que requiere semejante empleo aunque si me consta que

\section{el comun o la maior parte de el lo pide.5.}

A este tipo de discurso se opone la relación hecha por Pablo Ramos. Pero también esta última referencia permite ampliar el cuadro de interpretaciones sobre las circunstancias que rodearon a su alejamiento del cargo de cacique. Una primera interpretación fue la que hizo su hermano, introduciéndola en una serie premeditada de hechos destinados a destruir a la familia Ramos; una segunda interpretación, que puede ser contemporánea a ésta, introduce la destitución dentro de otra serie de eventos referidos a la incapacidad de Pablo Ramos en el ejercicio de su cargo (falto de bienes y de aplicación); por último, el propio Pablo Ramos se posiciona frente a ambas eliminando la "destitución" y reemplazándola por una renuncia forzada por los "impedimentos de acsidentes" (enfatizando que su desempeño se realizó en un lapso de cuatro años y meses "con toda puresa y aplicación al Real Servicio"), en la que se mantuvo, en todo caso, el orden ancestral de sucesión. Se trata, en este último caso, de dar una representación armónica en la sucesión y en el ejercicio del cargo.

El análisis que hasta aquí hemos desarrollado ilustra suficientemente los esfuerzos de la familia Ramos por fortalecer una estrategia familiar de predominio y prestigio frente a las familias principales de la nobleza atacameña. Es posible que los dichos que el corregidor Andrés Estevez reprodujo de un "sujeto de verdad", que mantuvo en el anonimato, haya correspondido a la opinión de otros principales interesados en el cargo o de algún indio del común. En el documento de Agustín Ramos es claro el rechazo que éste tiene ante las intenciones del corregidor Argumaniz por colocar, en el cargo de cacique, a un indio que no posee derecho de sangre. Por el contrario, consideraba legítimo que este cargo fuera disputado por otros miembros de familias principales que com-

$\begin{array}{ll}52 & \text { Ibid., foja 1r. } \\ 53 & \text { ABN, E 1781, No 7, foja 1r. } \\ 54 & \text { Ibid. } \\ 55 & \text { Ibid., foja } 8 \mathrm{v} .\end{array}$


partían con él el mismo derecho. Respecto de esto último, los juicios de Pablo Ramos comportan un matiz: "por ser acreedor de mejor derecho que ninguno de otros principales por Sangre noble y otras circunstancias que adorna toda mi familia." Tal vez esta acentuación tiene por objetivo desestimar a potenciales rivales (de las familias principales) que hasta aquí habían permanecido pasivos frente al prestigio logrado por el cacique Agustín Ramos. Pero estas sospechas pudieron estar infundadas, pues ningún pretendiente se presentó "berbalmente ni por escrito" y el propio $\mathrm{Pa}$ blo Ramos no dio información alguna sobre el derecho que le asistía. Siguiendo los procedimientos de las ordenanzas, el corregidor elaboró una terna en la que incluyó al propio Ramos, sin embargo respaldó a los dos primeros candidatos. Curiosamente, los dos candidatos pertenecían a familias principales de Atacama. A pesar del juicio adverso que el corregidor recogió de Pablo Ramos se vio obligado a reconocer que éste tenía un fuerte respaldo en el común de indios. Dejemos hasta aquí la historia de los Ramos, no sin antes decir unas últimas palabras sobre el tema tratado.

Las presiones sufridas por la familia Ramos la llevaron a combinar una serie de tácticas de resistencia, entre las cuales, la lucha por las palabras tuvo por efecto, más notorio, la producción de una memoria familiar que contrarrestó, durante un buen tiempo, cualquier intento de deslegitimación. Aunque estuvo lo suficientemente adornada como para tener el apoyo del común de indios, incluso en los momentos que eclipsaba la influencia de los Ramos, en su contra jugó la ausencia de una fortuna familiar que les permitiera urdir con mejores hilos la trama de su memoria. ${ }^{56}$

Volviendo a la coyuntura que hemos venido ana- lizando, cabe seguir explorando la rearticulación de fuerzas sobre la que se apoyó la rebelión de Ingaguasi. A la consolidación del poder del cacique se agrega la de una red de alianza que une, por lo menos, a gran parte del poder político indígena. El cacique Agustín Ramos nombró un cierto número de alcaldes indígenas sin considerar la opinión del corregidor, echó derramas contraviniendo las disposiciones reales e incluso retuvo parte de los tributos debidos al corregidor. ${ }^{57}$ Esto fue descrito por el corregidor Argumaniz como un exceso que había que castigar. Pero lo que para el corregidor era un exceso era más bien el producto de una nueva forma de relaciones y alianzas que se generaban en el mundo indígena. Si se trataba de ganar terreno en la lucha por la hegemonía del cacicazgo, imponiendo la propia memoria familiar como la "memoria del cacicazgo," era imperativa la rearticulación de las propias relaciones de poder al interior de las comunidades atacameñas.

De otra parte, los propios sucesos de Ingaguasi no se entienden sin una estrategia coordinada de resistencia étnica. Existió en el mineral una estructura política indígena que, aun cuando era el producto de la arquitectura colonial, jugó un papel protagónico en el desenvolvimiento de los acontecimientos. Alejo Ventura, segunda persona del gobernador y principal del asiento, y Diego Siaris, principal del asiento y probablemente descendiente de un antiguo gobernador indígena de Atacama, fueron sindicados como los autores del robo de cincuenta onzas de oro, como los principales instigadores del levantamiento y debieron sufrir prisión durante algunos años, mientras se realizaban las averiguaciones del caso. Del escrito redactado por estos principales, hay un párrafo que describe una escena que ilustra lo que aquí estamos sosteniendo, a propósito de la estrecha vin-
No obstante, esta situación no se mantuvo por mucho tiempo. Hacia 1792, un Pedro Pablo Ramos figuraba como gobernador de la provincia de Atacama (veáse "Revisita de Atacama de 1792" AGI, Lima, 895). Con el mismo nombre aparece un cacique cobrador en las revisitas de 1777 y 1786 . Si consideramos las edades que aparecen registradas en 1777 (el cacique cobrador tenía 48 años) y 1792 (el gobernador tenía 49 años), podemos concluir que 1) se trata de dos personas distintas y 2) que el gobernador de $1792 \mathrm{es}$ el mismo Pablo Ramos (quien en la revisita de 1751 contaba con sólo 8 años) que ha vuelto a recuperar la posesión del cacicazgo de Atacama. Otra afirmación merece una breve observación. Que los Ramos aparezcan, hacia fines de la década de 1770, como una familia destituida de bienes puede llevarnos a engaños. Una relativa fortuna familiar debió permitirle a los Ramos una mejor maniobra, pues era necesaria para hacer frente a las cargas económicas que los corregidores imponían a la población indígena. Asumir el cargo de cacique significaba quedar expuesto a un 
culación de las autoridades étnicas: "hallarse en camino nuestro Gouernador don Agustin Victorio Ramos con los demás principales del referido nuestro pueblo conduciendose a esta corte a viar de nuestras defenzas." 58

Sin embargo, no habría resultado eficaz la alianza entre las autoridades étnicas si no hubieran contado con el apoyo del común de indios. La información proporcionada por los chasquis enviados por el corregidor fue de gran utilidad porque les advertía de las intenciones del corregidor permitiéndoles diseñar algún tipo de tácticas frente a eventuales contratiempos. Esta verdadera red de informaciones se extendía más allá de los límites jurisdiccionales de la provincia apoyándose en los tributarios atacameños dispersos en la provincia de Tucumán. Los intentos del refugiado corregidor Argumaniz por someter a los sublevados de Ingaguasi, resultaron frustrados porque:

\section{haviendo transendido estas providencias a los yndios de Atacama, que viven disper- sos en dicho valle [Calchaquí], dieron quenta de ellas a los que residen en el ex- presado mineral Yngaguasi, y que estos los comunicaron a los qué viven en el interior de dicha provinsia, y teniendo noticia el corregidor, que asi estos como aquellos havian resuelto desamparar aquella juris- dicción, y aucentarse a otras como lo eje- cutaron el crecido numero de yndios que ocupaban dicho mineral (AGNA, interior, Leg. 6, Exp. 8, foja 3v).}

Aunque dispersos, los grupos atacameños continuaron manteniendo lazos que derivaban de procesos étnicos que tenían, por otra parte, un resultado no previsto por los esquemas de dominación coloniales, cual es el de una instancia productora de un sentido de pertenencia. La dispersión, en tanto patrón cultural y mecanismo de resistencia, será, como veremos más adelante, una cuestión que el poder colonial deberá resolver para eliminar los obstáculos que impedían la circulación del poder real. Por lo pronto, es conveniente examinar con un mayor detenimiento aquello que hemos denominado como instancia productora de sentido étnico.

\section{Los miserables indios y los viracochas}

Las vestimentas, las lenguas y las procedencias territoriales de los indios fueron utilizadas, entre otros, como marcadores identitarios. Pero el recurso a lo identitario no expresaba la "conciencia de sî" de un grupo étnico sino que era más bien parte de un mecanismo de inclusión y sujeción coloniales. El mundo de las castas jerarquizadas requerían de la imposición de criterios de identificación y delimitación para evitar las confusiones y los desordenes que suscitan una realidad heterogénea. Es a partir de ésta que se fundamenta la distribución y localización de las castas en el espacio colonial. Lo indio, lo negro o lo mestizo, no es sólo el producto de una sobredeterminación discursiva, es también el producto de una subdeterminación "racial", de sus inclinaciones naturales o, para decirlo en el lenguaje de la épo$\mathrm{ca}$, del genio de las castas. Las castas no hacen otra cosa que reproducir una estructura visible, la de la constitución de un indio o un negro, que "los hace difícilmente unibles". Esta oposición "conduce á mantener sana y sin alteración nociva este cuerpo político." 59

De aquí se deriva una primera cuestión: es la propia dominación colonial la que enfatiza las oposiciones entre las castas. El genio rudo y simple de los indios fundamenta la apropiación de sus cuer- rápido empobrecimiento; hubo individuos que Ilegaron a huir de la provincia antes que asumir el cargo de cacique o que fueron removidos por no cubrir el pago de tributos (vcáse Hidalgo 1985: 175). Esta fortuna que se dilapidaba para cubrir las cargas que se imponía a la población indígena permitió a los Ramos acrecentar su propio prestigio. Este prestigio acumulado permite comprender el fuerte apoyo que le dio el común de indios a la empobrecida familia Ramos en los momentos que Pablo Ramos era enfrenta- do con miembros de familias más solventes (para la relación entre consumo de bienes personales en actividades comunitarias y acumulación de prestigio puede ser ilustrativo el ejemplo que Wolf [1972] señala para los campesinos mesoamericanos).

57 Ibid., foja $7 \mathrm{v}$.

58 “Escrito...", AGNA, interior, Leg. 6. Exp. 8, foja $14 \mathrm{v}$.

59 "Memoria del Virrey José Antonio Manso de Velasco" (Memorias 1859: 98). 
pos pero, en el movimiento de esta apropiación, se les reconoce como "miserables personas" y una serie de privilegios espirituales y temporales. ${ }^{60}$ Esta sobredeterminación del discurso que articula y fundamenta una dominación entrega, de otra parte, un lenguaje a partir del cual se puede fundamentar una protesta, generando el espacio para la rebelión. El indio como "miserable persona" es un enunciado que se recoge en la formulación de una "economía moral", es decir, la de una moralidad incorporada a la tradición étnica y sancionada por la propia autoridad colonial. Los principales indígenas justificaron los hechos de carnestolendas como una defensa contra un tumulto protagonizados por los viracochas contra los miscrables indios. Esta última es una oposición que nos viene formulada del único testimonio indígena que conocemos para la rebelión de carnestolendas. Es evidente que la expresión viracocha es utilizada aquí como sinónimo de español, de acuerdo a un uso extendido en el área andina. Dejando de lado, por otra parte, el significado que tiene el referente viracocha en los relatos míticos andinos, nos interesa retomar el valor peyorativo que, al parecer, le es asignado en el escrito de los principales indígenas. Este mismo valor aparece en una declaración referida a acontecimientos posteriores, pero por vía de un español que reproduce un supuesto comentario de los indios. De acuerdo a éste, los indios pretendían "echar de aquí a todos los viracochas y españoles matandolos a todos sino se iban luego."

Los españoles obtenían sus ganancias a expensas del trabajo realizado por los indígenas. Eran éstos los que los proveían de oro por el cual aquellos obtenían mayores ganancias, que hacían irrisorio el intercambio por plata u otra mercancía, situación que se veía agravada por la actuación del corregidor, sobre todo en lo concerniente al reparto. A partir de las mismas declaraciones del corre-
Esta no es una situación exclusiva de los indios ya que el reconocimiento de miserabilis, y el sistema protector que originaba, pertenecía a una vieja tradición curopea en la que tenían cabida los pobres, los lisiados, las viudas y los huérfanos. "Este sistema permitía el aceeso directo a las cortes reales, abreviar los procesos legales, reducir o eliminar los honorarios y los costos legales y brindar consejo legal con honorarios reducidos o sin ningún pago" (Borah 1985 : 261). El mismo autor señala que. aun cuando los in- gidor Argumaniz, podemos plantear que uno de los problemas más candentes en las relaciones entre indígenas y españoles derivaban del mismo reparto. De acuerdo a Argumaniz, el cura Miguel de Olmedo había capturado las voluntades de los indios con la promesa "que se libertaran de pagar el reparto"62. Era éste una antigua carga de la que los indígenas atacameños habían tratado de desprenderse, en épocas anteriores, sin ningún resultado que les fuera favorable. La lucha contra el reparto formaba parte de una vieja táctica de resistencia anticolonial. En la medida que profundizaba la desigualdad de las relaciones, el reparto no hacía más que poner en evidencia la subordinación y el sometimiento de los indios. De acuerdo al Corregidor Argumaniz, sus antecesores no habían podido cobrar los repartos por lo que los indios estaban acostumbrados:

a quedarse con ellos para remediar las ne-
cesidades a que su innata desidia, vicios y
perbercidad los conduce, y más quando
hallan apoyo para ello y para solicitar con
falsas imposturas desconceptuar al Corre-
gidor y entretenerlo de esta forma, con
continuados pleitos, y ber si por ellos se le
suspende del empleo para berse libres del
rexto de pagar lo que tan justamente le
deben (AGNA. Int., Leg. 6, Exp. 8, f. 6r.)

Frente a una tradición indígena que ve en el reparto un mecanismo de expoliación y de extracción de recursos, operado bajo el contexto de relaciones asimétricas, el poder colonial introduce la reclitud y la justeza como elementos que describen el mecanismo y la circulación del reparto. La circulación de las mercancías se inscribía en el marco de una regulación equitativa, sancionada por la autoridad real, y cuya distribución-retribución era realizada "justa y cristianamente. ${ }^{\text {"63 }}$

dios fueron en su conjunto reconocidos como miserabilis, este reconocimiento exceptuaba a los caciques y sus primogénitos y los pucblos de indios en tanto organización corporativa.

61 "Declaración de don Isidro Salinas" AGNA, Criminales. Leg. $10 . \mathrm{N}^{\circ} 3$, fojal $13 \mathrm{v}$.

62 "Informe del Corregidor Argumanis...", AGNA, Leg. 6. Exp. 8, foja $5 v$.

63 Ibidem, foja 6r: 
El cuestionamiento del reparto no implica, sin embargo, el cuestionamiento de una dominación global. Todo parece indicar que los informes de los corregidores exageraron las reales motivaciones de la rebelión indígena. Más arriba hemos citado el testimonio de un español en el que se afir. ma la intención de los indios de echar a los viracochas de sus tierras. Esta situación está referida en el informe del Corregidor Paniagua, fechado en noviembre de 1777, quien sostiene que a su llegada a la provincia se hallaban:

sus avitantes tres años hase, sin conocer al Rey nuestro señor por soverano, ni a sus justicias y corregidores, y para confirmación de ello hauian echado a pedradas a todos los mineros y españoles que componian este asiento y mineral de donde sacaba su Magestad un correspondiente ingresso de los quintos, expresando tumultuariamente que estas tierras no eran del Rey de España, ni lo conocian por tal, y que asi vien podian salir de ellas todos los españoles, sino querian que los matasen a todos. ${ }^{64}$

La situación descrita sólo estaba referida al mineral de Ingaguasi, pues la capital de la provincia estaba en normalidad al igual que las demás jurisdicciones. El afrentado corregidor Argumaniz había incluso recolectado información, para una relación de méritos, en la que habían actuado como testigos varios principales indígenas, entre ellos el cacique gobernador don Agustín Ramos ${ }^{65}$ Además, habían solicitado que se designara un juez que averiguara los sucesos. Los propios indígenas, por intermedio del cacique gobernador don Agustín Ramos, cubrieron los costos del traslado del corregidor Paniagua para que este realizara tales acciones. Por otra parte, el propio corregidor Paniagua no había llegado a la provincia con las

AGNA, Criminales, leg. 10, $\mathrm{N}^{\circ} 3$, foja $2 \mathrm{r}$. de Argumaniz, corregidor que ha sido de la provincia de Alacama", AGl, Charcas 425 (en adelante AGI, Charcas 425)

"Paniagua v/s Oficiales Reales", 3er cuaderno, fojas $28 v-3$ ir, Archivo General de Indias, Charcas 529. K'ulta remitimos al estudio de Abercrombie (1993). Por su parte, Saignes, criticando las afirmaciones tra-

fuerzas necesarias para someter tan grave sublevación, pero sí con una gran cantidad de objetos que se contaban en "docenas" y "gruesas", como seis docenas de navajas y cinco docenas de cuchillos, además de cantidades de botones, abalorios y sortijas, ciento veintiséis herraduras, herraduras, quinientos cuarenta y seis clavos, siete combos de fierro, veinticuatro docenas de cuchillas, y otras mercancías. ${ }^{66}$ Obviamente, que tales cantidades de mercancías estaban destinadas al reparto entre los naturales.

Sin embargo, aun cuando es evidente que los informes de los corregidores exageraron las intenciones que tuvieron los atacameños, nada impide sostener que entre algunos miembros de la comunidad haya persistido un rechazo a la dominación de los viracochas y que, efectivamente, hayan pronunciado tales afirmaciones en los momentos que la embriaguez hace más suelto el hablar restituyendo las rutas de una memoria que, a pesar de la colonización, sigue ligando a los indios a una historia que no se confunde con la historia de la dominación hispana.$^{67}$ En aquella historia, que es también la de una reelaboración del pasado prehispánico, se restituye, en líneas gruesas, un tiempo en el cual la tierra estaba en manos de los naturales. Para los grupos hegemónicos, la existencia de una memoria indígena fue considerada como un discurso alternativo y una potencial fuente de resistencia, ${ }^{68}$ tal como lo manifestara el virrey José Antonio Manso de Velasco al plantear la necesidad de eliminar las procesiones que la nobleza inka realizaba en la capital del virreinato:

memoria que en medio del regocijo los entristece, y, pompa que les excita el deseo de dominar y el dolor de ver el cetro en otras manos que las de su nación (Memorias, tomo III: 98 ). dicionales sobre la embriaguez entre los indios, sostuvo que ella permitió, a una gran parte de la población indígena que estaba excluida de los rituales prehispánicos, junto con un acceso a otra rcalidad la construcción de un "canal de expresión propio, autónomo y (aun si ambiguo) subversivo" (Saignes 1993: 71). tonomía de los grupos subalternos cobró una mayor relevancia tras la rebelión de Tupac Amaru, cf. al respecto Hidalgo (1999 Ms). 


\section{Los rostros del colonizado}

Tras la revuelta de carnestolendas, un panorama carnavalesco predominaba en el mineral de Ingaguasi:

\section{[el corregidor] aucente de su provincia, y sin uzo, ni ejersicio en su ministerio, los yndios viviendo a su libertad, los tributos de su Magestad sin cobrar, las ordenes del superior gobierno, y de Vuestra Alteza sin su debido cumplimiento por cauza de di- cha ausencia, el importe de las bulas sin recaudar, el papel sellado que se remitio de las Cajas de Potosi, sin recoger, la vicita general sin poder concluir ${ }^{69}$}

La dominación colonial había incorporado al indio dentro de dispositivos de control político-religioso-económico, que estuvieran "viviendo a su libertad" no era otra cosa que la ausencia de los dispositivos de sujeción coloniales. Al romperse los lazos de sujeción, los indios pasaban de un estado de civilización, en el cual se les había tratado de reducir, a un estado de barbarie, al que los arrastraba su innata condición. Hasta el presente, sostenía el corregidor Argumaniz, los indios de la provincia de Atacama habían vivido "montaras y licensiosamente sin haver querido reducirse a población reconoser subordinación, ni superioridad." ${ }^{\text {"7) }}$ El colonizado asumía, pues, los rostros que la dominación colonial le había impuesto: montarás, licencioso, rústico, vagos, borrachos, gentiles, entre otros. Rostros forjados por una economía discursiva sin la cual no podría funcionar la dominación colonial.
En otro tiempo, la lucha contra las supersliciones e idolatrías se había inscrito en una economía de la dominación que justificó y legitimó el control sobre los cuerpos, los bienes y los territorios de los indígenas atacameños. La libertad en la que vivían los indios era el caldo de cultivo para la acción del demonio, las supersticiones y la práctica de las idolatrías, todo lo cual fue comprendido dentro de la gentilidad. Pero este tipo de discursos había perdido el atractivo que despertara antaño cuando los extirpadores de idolatrías podían asegurarse una buena posición en la carrera eclesiástica con la quema de wak'a y poblados de idólatras.

A diferencia de este discurso, los corregidores de la década de 1770 recurrieron a un discurso que correspondía a una "ideología históricamente orgánica" y cuyos enunciados principales se construían a partir de la oposición barbarie/civilización. ${ }^{71}$ En su relación de méritos, el propio corregidor Francisco de Argumaniz sostuvo que:

dirijio todas sus miras no solo al cumplimiento de las Reales intenciones en la administracion de justicia, y buen trato de sus moradores, sino tambien a la sivilisacion de aquella inculta gente en quien aun perseberaban muchos efectos de la Barbarie. ${ }^{72}$

Un conjunto de rasgos (insolentes, intrépidos, provocativos, desobedientes) y la ausencia de un dispositivo reduccional de control habían posibilitado el alzamiento de los indios, cuyo movimiento implicó el triple rechazo de la subordinación de-
69 AGNA. Interior, Leg. 6, Exp. 8, foja 7r.

70 Informe del Corregidor Argumanis...", AGNA, Interior, Leg. 6. Exp. 8, foja 7v.

71 Unas aclaraciones necesarias. El que establezcamos una secuencia entre dos prácticas discursivas, no implica una secuencia evolutiva respecto de "mayores grados de racionalidad" del discurso de dominación, simplemente localizamos estos enunciados en el momento de su irrupción en un discurso y su cronología no presupone sentido evolutivo alguno. Tampoco se trata de oponer un discurso de tipo tradicional, que acentuaría la oposición paganismo/cristianismo, y uno moderno que acentuaría la oposición barbarie/civilización, como veremos más adelante, el discurso sobre la civilización asume el cristianismo como parte integrante. Por último, retomamos de Granısci la noción de "ideología históricamente orgánica" para señalar que la oposición barbarie/civilización le es necesaria al proceso hegemónico en la medida que organiza un espacio a dominar y "forma el terreno en el cual se mueven los hombres, adquieren conciencia de su posición, luchan, ctc." (Gramsci 1958: 58). 
bida a la justicia, de toda vecindad y el de la religión cristiana, aunque este último no era algo que pudiera afirmarse fehacientemente. ${ }^{73}$ Para el corregidor, el alzamiento de los indios no sólo colocaba el problema de la sujeción de los indios a un proyecto civilizador, sino que permitía vincular este proyecto con el desempeño de sus propias funciones. Que se hubiera producido el alzamiento no podía achacarse a deficiencias en el cumplimiento de la administración del corregimiento, sino que era debido a la casi nula existencia de dispositivos de sujeción, y esta era una situación que, al momento de producirse el alzamiento, venía paliando el propio corregidor.

El corregidor Argumaniz describió a Atacama como una "misera provincia, cuia destitucion, y desamparo en materia de mantenimientos, nunca seria bien ponderada, pues hay ocaciones en que por no perder la vida es indispensable el salir de ellas a sus naturales." ${ }^{74}$ El corregidor hacía una lectura interesada -que lectura no lo es- del modelo de asentamiento atacameño, dejando de lado, precisamente, el hecho que, salir de la provincia en época de carestía, era parte de un patrón de subsistencia. La formación de cajas de comunidad y de depósito de semillas, consideradas por el corregidor como instrumentos adecuados para la solución de los "pobres vecinos" de Atacama, formaban parte de un proyecto global de sujeción de los grupos atacameños.

Ese proyecto de sujeción abarcaba tanto el control sobre la movilidad territorial como sobre el imaginario de los grupos atacameños. En esto el corregidor Argumaniz no era ningún innovador,

"Informe del corregidor don Francisco de Argumaniz...", AGNA, Interior, leg. 6, exp. 8, foja $2 v$.

"Expediente que..." AGI, Charcas 425, foja $1 v$.

Se ha restado importancia al papel disciplinador de la estructura de pueblo, reduciéndola a la proyección de una cicrta mentalidad europea que veía en el pueblo, la villa o la ciudad, el modo normal de asentamiento humano (Cf. Romero 1986; Gade 1991). Sin embargo, con estas afirmaciones se permanece en el efecto de una idcología que presenta el vivir en población como un modo natural de sujeción. Lo que interesa lo que hacía era cumplir antiguas disposiciones reales, entre las cuales, muchas de ellas, habían sido nuevamente reformuladas. Pero se percató de su importancia a la hora de rearticular el control sobre la población indigena, ${ }^{75}$ sobre todo después de la rebelión de Ingaguasi: "que para quietud, y pacificacion de dichos yndios, sean estos reducidos a Poblado, y vida sosiable como los demas del Reyno."76

Aunque el corregidor proponía la reducción a poblado como un mecanismo que, contrarrestando la dispersión de los grupos atacameños, permitiera una recolección menos dificultosa de los tributos, no dejó de tener en cuenta los alcances que esta medida podía provocar:

\section{los dichos yndios que andan dispersos se recojeran a los Pueblos de su origen, se cultibaran la tierra de estos que hasta aho- ra se mantienen yermas, se civilisaran en los docmas de Nuestra Santa Fe Catholica y se evitara que vivan muchos de ellos bagantes y poco menos que gentiles ${ }^{77}$}

La reducción a pueblos, el cultivo de las tierras yermas y el conocimiento de los dogmas religiosos, colocan en escena un tipo de tecnologías cuya manipulación reactivaría un proceso de aprendizaje y sujeción coloniales, "y se evitara que vivan muchos de ellos bagantes y poco menos que gentiles". Aquí no se trata de un mero juicio de valor sobre el "indio", detrás de este último enunciado hay una precisa operación de (re)conocimiento --aunque ideológica -- que permite hacer visible al otro en el horizonte de un discurso de domina- 
ción. ${ }^{78}$ Vagantes y gentiles son, precisamente, los rostros mediante los cuales se reconoce y localiza a individuos para su transformación en sujetos de una dominación; además, una economía de la dominación requiere este movimiento de reconocimiento y localización porque de lo contrario, como lo ha señalado Laẻnec, se "habría dejado al orden civilizado sin cimientos lirmes, y por tanto bajo permanente amenaza de hundimiento" (Laënec 1993: 205).

Eliminar la barbarie, y con ello toda fuente de subversión del orden, pasaba por eliminar el soporte que permitía su reproducción, la "misera provincia". Las tierras yermas eran el elemento más visible de la barbarie, y su cultivo produciría una transformación radical de la "inculta gente" que vagaba por la provincia. La construcción de acequias, como la que ordenó construir Argumaniz en el pucblo de Chiu Chiu, tenían por propósito esta transformación del paisaje, "para que con ella pudieran fertilisar sus campos los yndios, y hacer sementeras, y no padeciesen las incomodidades que anteriormente havian experimentado." tierras cultivadas permitían, por otra parte, una concentración más estable de la población indígena, amén de ocupar a esa misma población en el cuidado de las sementeras. Al intentar neutralizar el patrón de movilidad atacameño, el corregidor pensaba atacar de raíz la causa de la vagancia de los indios, los peligros de la gentilidad y una dispersión descontrolada que favorecía el amotinamiento y la conspiración.

La "misera provincia" hacía visible la barbarie en la que vivían los indios; las medidas tomadas por el corregidor apuntaban a operar un cambio en el paisaje. Pero si los indios habían estado viviendo como búrbaros era posible que practicaran o arriesgaran caer en la gentilidad. Una cuestión sobre lat cual el corregidor había hecho ya mención en su Informe sobre los sucesos de Ingaguasi ${ }^{80}$, pero que climinó de su relación de méritos aunque estableció que entres los indios de la provincia "aun perseberaban muchos efectos de la barbarie". Y la gentilidad ocupaba un lugar central en el discurso sobre la barbarie era uno de sus efectos), del mismo modo que el cristianismo en el discurso de lá civilización. ${ }^{81}$

Que los indios "se civilisaran en los docmas de

Nuestra Santa Fe Catholica" implicaba la puesta en escena de aparatos ideológicos que colonizaran y controlaran el imaginario de los grupos subalternos: iglesias, casas de cabildo, cárceles y escuclas. En el proyecto del corregidor Argumaniz, la escuela ocupaba un lugar central para:
la instrucción de la jubentud de aquellos naturales a fin de conseguir por este me- dio el que no solo se instruyan en los rudi- mentos sino tambien que olvidando su an- tigua aprehendan el idioma castellano como su Magestad lo encarga ${ }^{82}$

Cumpliendo una orden de la Real Audiencia, ${ }^{83}$ el corregidor Argumaniz inició, hacia 1776, la construcción de escuelas en los pueblos de Atacama, en el anejo de San Lucas de Toconao y en San Francisco de Chiu Chiu. ${ }^{8+}$ Se trató de una política que afectó a todo el virreinato y que estaba vinculada con la reactivación del control hegemónico. Basta recordar que las propias Leyes de Indias, recogiendo una real cédula de 1550 , establecían la fundación de escuelas de lengua castellana para la enseñanza cle los indios como una manera de resolver las dificultades que enfrentaba la evangelización de los naturales: 1) las cátedras destinadas a los sacerdotes, para el aprendizaje de las lenguas indígenas, eran insulicientes a raíz de la variedad de estas lenguas; 2 ) los misterios de la fe no podían ser explicados en la más perlecta de las lenguas indígenas sin caer en disonancias e imperfecciones (Recopilación [1681] 1973: 190). Tema que volvió a preocupar al Concilio Limense 
de 1772, entre cuyos capítulos se estableció la enseñanza de la lengua castellana y el restablecimiento de las escuelas de primeras letras, pues, el aprendizaje de la lengua castellana, junto con mejorar y facilitar la instrucción en materia de religión, lo era también del estado y gobierno político. La ruina en la que se encontraban las escuelas de primeras letras y la carencia de éstas en varios repartimientos, imposibilitaban la ejecución de estas medidas por lo que el Concilio solicitó al Virrey instruir con todo vigor y constancia sobre esta materia (Vargas 1952: 18-19).

El corregidor siguió las disposiciones de la Real Audiencia de La Plata en lo concerniente al funcionamiento y los objetivos de las escuelas. A fuer de severas medidas se fue imponiendo el olvido de la lengua nativa y el aprendizaje del castellano. La prohibición de hablar la lengua en las escuelas se extendió también a la intimidad de los hogares. Otros modos de expresión sufrieron esta violenta colonización:

no les permitan tener entre ellos conversaciones indecentes ni menos les toleren jurar con ofensa de Dios, como ni tampoco el que beban licores, ni otros brebajes, de que de este modo se eviten las borracheras a que son inclinados desde tierna edad corrijiendo estos vicios e imperfecciones por todo los modos posibles.s.

Este control sobre los grupos subalternos adquirió la forma de un dispositivo ortopédico en la medida que su propósito era corregir los vicios e imperfecciones de los indios. A través de esa ortopedia se trató de neutralizar los modos de expresión que daban forma a una cierta "autonomía cultural", y, que, por fuerza de la representación, pasaron a forma parte de los vicios a corregir.

¿Cómo percibieron los indígenas esta colonización de sus memorias? Sobre esta cuestión en los documentos hay un gran silencio. Por la investidura de sus cargos, las autoridades indígenas estuvieron obligadas a fiscalizar el funcionamiento de las cajas de comunidad, la asistencia a clases, la aplicación de castigos a quienes transgredieran las disposiciones reales, etc.; a lo que se añade que fueron indígenas los encargados de dar instrucción en las escuelas y, además, los recursos para su mantención se sacaban de las propias cajas de comunidad. Esto podría indicar que los indígenas observaron con simpatía, o, a lo sumo, con cierta indiferencia, las acciones emprendidas por el corregidor Argumaniz, máxime si lo secundaban en sus planes. Incluso, en el único testimonio que contiene una percepción indígena de estos acontecimientos ${ }^{86}$ no hay ninguna afirmación que discuta los planes del corregidor, por el contrario, todos coinciden en que éstos han significado un gran fomento para los pueblos de indios. Sin embargo, hay un gesto que se repite en cinco de un total de seis declaraciones: los testigos hicieron su declaración en la "lengua provincial", aun cuando se reconocía que eran suficientemente ladinos y versados en el idioma castellano. El único testigo que realizó la declaración sin intérprete fue el cacique Agustín Victorio Ramos quien hablaba únicamente el castellano.

Para el corregidor había una profunda vinculación entre el fomento de los pueblos y la civilización de los indios del mismo modo que había una relación entre la barbarie y la incultura de la tierra y sus gentes. En otras palabras, había que atacar la barbarie en el medio que permitía su reproducción: las tierras yermas, la vagancia de los indios. la gentilidad, la incultura, etc.

Pero las cosas llegaban a su término para el corregidor Argumaniz, pues la Audiencia había nombrado corregidor de Atacama, el 8 de octubre de 1776, a don Josef María Paniagua --quien había sido corregidor de Santa. Después de haber tomado posesión de su cargo en Lima, el 4 de febrero de 1777, Paniagua arribó al puerto de Cobija el 11 de abril de ese año. Inmediatamente, escribió a los Oficiales Reales de Potosí, indicándoles que en el plazo más breve pasaría a entregar las fianzas respectivas para el cobro de tributos. No imaginaba Paniagua las distancias que debía recorrer y lo duro que sería su tránsito por los caminos de Atacama. El y su familia llegaron enfermos al pueblo de San Pedro después "de la navegación tan larga y del fragoso y dilatado camino."
Ibid., foja 5v.

“Expedicnte que acredita...", AGI, Charcas 425, fojas $17 v-30 r$. 
Paniagua llegaba también a la provincia "sumamente destituido de dinero" por lo que:

\section{le fue preciso haser gran furia y comercio en rescatar oro con la mesma plata de al- cabala y visitas de casas de este asiento dando a los indios alcaldes y mandones para maior combeniencias, no escapando ni aun las pobres mugeres que amasan un poco de pan la exaccion de quatro pesos de visita y pencionando a los gobernado- res y comunidad de indios con el trabajo y construccion de la casa nueva que mando haser sin pagarles jornal alguno y quitar- les con esto el que puedan atender a la primera obligacion de pagar y cobrar sus tributos y a sus casas y familias en las gran- des distancias en que viven los pobres in- $\operatorname{dios}^{87}$}

Las exacciones y las obligaciones que el corregidor Paniagua impuso, a las autoridades étnicas y a la comunidad de indios, no hicieron más que acrecentar el rechazo contra un deteriorado poder provincial. El rechazo sc fundamentaba en una "cconomía moral" que había incorporado las garantías y privilegios de indios sancionados por la Corona. Que los indios no recibieron jornal por la construcción de la casa no sólo contravenía las disposiciones reales sino que, por sobre todo, un sistema de obligaciones sustentado en la reciprocidad y en la simetría.

En el intertanto, Paniagua certificaba cada una de las obras realizadas por el corregidor Francisco de Argumaniz. Otra de las tareas que tenía pendiente, era la averiguación de los sucesos de 1775 --ordenada por la Audiencia a solicitud de los principales indígenas Ventura y Siares.

\section{"Las tierras no son del Rey"}

El 26 de agosto de 1777 , el recientemente nombrado corregidor de Atacama, don Josef María Paniagua, emprendió camino hacia el mineral de Ingaguasi. El gobernador don Agustín Victorio Ramos lo proveyó, para cl viaje, con cinco mulas de silla y ocho de carga. La marcha fue forzosa, durando veintiún días, "a causa de los intemperies del tiempo según lo riguroso de la estacion de el. ${ }^{188}$
El 16 de septiembre, ingresaba, el corregidor y su comitiva, al convulsionado asiento de Ingaguasi cuyos "avitantes tres años hase, sin conocer al Rey nuestro Señor por Soverano, ni a sus justicias y corregidores. ${ }^{82}$ Una de las primeras obligaciones del corregidor era la "pacificación quietud y sosiego de animas de los que se hallasen conmovidos", para reducirlos a la paz y al reconocimiento del vasallaje debido al Rey y al obedecimiento de quienes en su nombre gobernaban los reinos y provincias. ${ }^{90}$ Pero para no interrumpir las actividades que se desarrollaban en el cercano mineral y, probablemente, para dedicar más tiempo a sus propios negocios, el corregidor esperó cerca de cinco días antes de reunirse con los habitantes de Ingaguasi.

La ocasión la brindó la misa. Concluido el santo sacrificio, el corregidor dio unos pasos en dirección a la plaza situada en el centro del poblado. En ella estaban ruidosamente congregados un gran número de españoles y naturales, quienes habían sido prevenidos, por los alcaldes y otras justicias, que esperasen la salida del corregidor. Haciéndoles guardar silencio el corregidor les expuso la intención de sus palabras:

solo a adbertirle a todos, con especialidad a los yndios la grande obligacion que tienen de ser fieles, agradecidos, obedientes y humildes vasallos al Rey de España nuestro soberano, y señor natural, que a costa de la sangre derramada de sus españoles, ha extendido los estandartes de la fe hasta estos bastos dominios que la divina omnipotencia le ha consedido a fin de que tenga la gloria de encaminar a estos neofitos a su Patria Celestial, sacandolos de las tinieblas, del abismo en que como gentiles

\footnotetext{
"Expediente informado de la contaduría y respondido del Si. Fiscal, sobre los Oriciales Reales, de Polosí despejado del Corregimicnto de Alacama a Dn. Joser María Paniagua". Ver "Informe del fiscal al Consejo", Archivo General de Indias, Charcas 529 , Cuaderno Tercero, foja $23 \mathrm{v}$.

88 AGNA, Interior, Lcg. 6, Exp. 8, foja $22 \%$.

89 AGNA, Criminales, Leg. 10, No3, foja 2r.

90 AGNA, Interior, legg 6, Exp. 8, foja 23r.
} 
vivian de antes; para lo qual, y que lograsen los pribilegios de españoles, y no ignorasen las claras y divinas luces del Evangelio, les ha embiado a estos Reynos y provincias, el gran Monarcha de España nuestro señor Prelados Arzobispos y Obispos, Religiones y Curas que los confiesen, y enseñen para merecer despues de esta vida, la felicidad incomparable de la gloria eterna a que todos debemos aspirar, despues que salgamos con la muerte de este valle de micerias, y trabajos, donde nos hallamos desterrados. Y que quedasen enterados y ciertos todos, que el que tubiese atrebimiento desde oy en adelante a faltar a la debida obediensia al Rey nuestro amable Soberano y Señor Natural, y en su Real Nombre a las justicias, Gobernadores y corregidores que goviernan estas provincias, expresando en juntas y tumultos que estas tierras no son del Rey de España, y que salgan los españoles de ellas desde ahora para entonces, los declara por traidores al Rey y su Real Corona"

Bien sabía el corregidor que las convicciones surgen de la escucha, o, parafraseando al Sexto Concilio, "nacen del oído y el oído requiere de la prédica." "Había entonces que persuadir, a través de las palabras, los ánimos de los conmovidos habitantes del asiento de Ingaguasi. El discurso del corregidor manipula e inventa un pasado que los indígenas están obligados a aceptar dentro de su imaginario como acontecimientos fundacionales. La secuencia se inicia con la llegada de los españoles a "estos bastos dominios" trayendo "los estandartes de la fe", acción que asume la forma de un acto de ruptura y origen pues "sacandolos de las tinieblas, del abismo que como gentiles vivian" encaminan "a estos neofitos a la Patria Celestial". De esta forma los indígenas pueden vincular, entre "otros privilegios de españoles", la memoria de sus origenes con el relato de la salvación: viven desterrados en este valle de miserias y trabajos para con la muerte merecer "la felicidad incomparable de la Gloria Eterna". Y esto no es una exageración, pues, ha sido la propia "omnipotencia divina" la que ha concedido a los españoles (en tanto súbditos del monarca español) el privilegio de extender los estandartes de la fe. En esta comunidad imaginada los indios tiene una doble adscripción: como miembros de la Patria Celestial y como súbditos del Rey. Este último referente es producido en la apertura del discurso en la que se interpela, mayormente, a los indios en su calidad de vasallos. Pero se trata de un vasallo de ánimo conmovido que ha descuidado el vasallaje debido al Rey como señor natural. El propósito de la interpelación discursiva es reintroducir al indio dentro de un sistema de sujeción y subordinación coloniales que no oculta, por otra parte, el hecho brutal de la dominación. Pues, junto con el pasado imaginado, se recuerda a los vasallos el castigo ejemplar que sufren "los traidores al Rey y su Real Corona":

\section{baian a trabajar perpetuamente durante sus vidas, a las minas de Potosí; y que sacandose de ellas, otro tanto numero de perzonas de todos sexsos, bengan a poblar esta prouincia de nuevo haciendose due- ños de ganados, casas, estancias, y demas que oy poseen ${ }^{93}$}

Interpelados por un pasado imaginado y compelidos por un potencial futuro, los indios "ofrecieron todos", ante el corregidor, "ser muy obedientes desde el dia de oy, y con semblantes alegres, repitieron Viva el Rey Nuestro Señor...". ${ }^{94}$ Sin embargo, que los indios pudieran ser despojados de sus casas y estancias venía a confirmar, para otra lectura, la frágil situación en la que se encontraban si sus tierras y sus vidas dependían del rey y de los españoles. En días posteriores, esa percepción se hará pública al ritmo de nuevos acontecimientos.

De entre la comitiva que acompañaba al corregidor José María Paniagua, lo que más pudo llamar la atención a los naturales debieron ser los baúles transportados con tanto cuidado. Con sus pertenencias el corregidor traía una gran cantidad de mercancías para ser repartidas entre los naturales. Pero sus planes sufrirían un fuerte revés.

Un par de días después que el corregidor se había

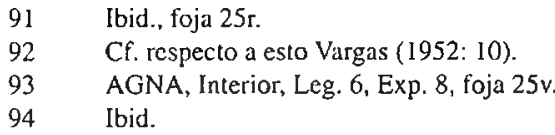

91 Ibid., foja 25r. AGNA, Interior, Leg. 6, Exp. 8, foja 25v. Ibid. 
dirigido a los vecinos de Ingaguasi, el cura Miguel de Olmedo llegó al asiento de Ingaguasi. No era de extrañar que arribara al asiento, pues, entre las diligencias que debía cumplir el corregidor estaba la venta de los dos trapiches que el cura poseía en el cercano paraje de Los Chorrillos. La venta no pudo concretarse porque "han quedado desamparadas estas minas, y no ay en este aciento minero español que la trabaje" y los trapiches resultan "de ningun balor ni efecto no haviendo perzona que los nesecite ni apetesca". ${ }^{95}$

Otra de las diligencias que debía cumplir el corregidor era la averiguación de la sublevación acaecida hacía ya tres años en Ingaguasi y en la que estaba presumiblemente involucrado el cura Miguel de Olmedo. El cura fue acusado de inducir y aconsejar testigos ante lo cual se le ordenó saliera de la provincia. Como la orden no tuvo el efecto esperado, y el cura permanecía aún en el asiento, el corregidor ordenó, el 10 de noviembre, a españoles y naturales no "puciese los piez en la casa del citado eclesiastico, hablase con el, o le solicitase para tratar sobre lo acahesido en este mineral" so pena de una multa para unos y azotes para los otros. ${ }^{96}$

En el transcurso del mismo día, "despues de depuesto el sol", los acontecimientos fueron adversos para el corregidor Paniagua. Las casas de cabildo y sus alrededores fueron escenarios de un violento suceso:

\begin{abstract}
donde entraron todos que se componía su numero de mas de cien hombres todos yndios cargados de piedras y con palos y entre ellos varios borrachos y que uno con capote azul cargado de bocas de fuego que era el que hacia de cabeza y otros dos el uno soldado con vanda colorada y espada en mano con pistolas como su compañero se entraron a parlar con dicho señor general ${ }^{47}$
\end{abstract}

Al ver a este tumulto golpeando las puertas de la casa del corregidor, la confusión reinó entre los españoles residentes quienes se mostraron también temerosos que aconteciese un nuevo levantamiento como el ocurrido hacía ya tres años. Quien encabezaba tan inusual comitiva era don Nicolás Lazcano, teniente de alguacil mayor de las Cajas

Reales de Potosí, quien había sido comisionado para apresar y embargar los bienes del corregidor Paniagua por no pagar los tributos debidos a dichas Cajas. El comisionado y su comitiva, que se reducía a dos soldados, se encontraban aposentados en la casa del cura. En el día de los sucesos, a eso de las oraciones, un mozo del cura llamado Jaona Yrribare y Jorge Pirola salieron, por orden del cura, a llamar a todos los indios "quienes venian corriendo y levantando piedras con las manos y de ellos se lleno toda la casa de dicho cura de donde salieron todos en acompañamiento de dicho comicionado". Al irrumpir en las habitaciones del corregidor, el comisionado procedió a quitarle el bastón y la vara de la Real Justicia y a embargar sus pertenencias.

Mientras tanto, la multitud de indios que se hallaba repartida en el interior y en las afueras de las casas de cabildo, "apadrinados en el manto de la noche" comenzaron a publicar, "con grande algarraza", que ya no tenían corregidor y era el cura quien reinaba, "pues havia savido traer juez a su misma casa y combocar a todos los naturales para que acompañando al dicho juez comicionado prendiese al general y se lo llebase de esta provincia para quedar ellos en la posesion de sus tierras, y a su libertad sin tener quien los mandase". ${ }^{98}$ Ante lo cual, los indios "enteramente ebrios" fueron ingresando a la habitación en la que se encontraba el atropellado corregidor sentándose a su lado "en tono de mofa y de burla". Así, "caiendose de ebrios", continuaron haciéndole burlas "faltándole al decoro queriendole tomar las manos unas veces y otras empujandolas poniendoselas en el hombro". Afuera los indios gritaban que "nos quedariamos en nuestras tierras que son de nosotros y no del rey de España; y ahora que conocemos el poder de nuestro cura no ha de quedar español ninguno aquí o los emos de matar sino salen prontamente". Entre los indios ebrios estaban también el cacique don Agustín Victorio Ramos y

95

96

97
Ibid., foja $23 v$.

Ibid., foja $34 \mathrm{v}$.

"Declaración de don Isidro Solis", AGNA, Criminales, leg. 10, $n^{\circ} 3$, foja 12v. Para evitar un exceso de referencias, el relato que sigue a continuación se ha armado, salvo indicación contraria, con la información de las declaraciones contenidas en la pieza documental citada. Ibid., foja $3 \mathrm{v}$. 
otros principales, a lo que se sumaba el hecho gravoso que "ningun yndio ni alcalde le hacen caso ya a dicho señor general estando en el dia todos mas en contra de la justicia y los españoles que estaban antes".

Una vez que el comisionado hubo cumplido su diligencia, se retiro de la casa del corregidor encaminándose hacia la del cura en la que se hallaba alojado. Afuera quedaron los indios, volviendo a armar un fuerte alboroto y profiriendo burlas contra el corregidor. Mientras algunos indios simulaban echar abajo la puerta de la casa del corregidor. Ante estos hechos, el corregidor envió varios recados al comisionado dándole aviso de lo que sucedía, pero resultaron infructuoso pues los indios continuaban con sus alborotos. El corregidor salió de la casa increpando duramente a los indios para luego dirigirse a la casa del cura en la que se hallaba el comisionado.

Todo esto era, sin duda, para los españoles, un plan urdido por el cura quien influía y había inclinado a los indios siempre en contra de los corregidores. Lo que encontraba cierta justificación en las palabras que escuchaban de los propios indios quienes no trepidaban en publicar el apoyo dado por el cura:

que su cura los ayudaba y no havia que temer porque les habia cumplido su palabra de que les traeria juez y lo hospedaría en su misma casa para aconsejarlo a efecto de que llegase de pleitos al corregidor y lo llebasen preso para que quedasen ellos en sus tierras que eran propias y no del Rey de España y que en esta confianza havian de echar de aqui a todos los viracochas y españoles matandolos a todos sino se iban luego. ${ }^{99}$

¿Esperaba el comisionado algún tipo de resistencia por parte del corregidor como para llegar con un crecido número de naturales armados con palos y piedras? ¿Porqué unos indios ebrios vociferaban que las tierras eran suyas y no había quién los mandase cuando la destitución era realizada por agentes del poder regional? Da la impresión de estar frente a esos acontecimientos en que la ambivalencia de los gestos y la ambigüedad de las palabras se hayan ya interpretados por un rela- to --en nuestro caso por el informe del corregidor y por las declaraciones de los testigos españolesque, no obstante, deja pendiente el "desentrañar lo que significa todo ese enredo de las ovejas" (Geertz 1992: 30). Parafraseando a Geertz, lo que interesa es descubrir cuáles son las estructuras conceptuales que informan sobre los actos de los atacameños, qué es lo dicho en sus gestos y discursos. Sin embargo, en este nivel hay un problema adicional, los "filtros e intermediarios deformantes" (Ginsburg 1997) que aniquilan el discurso del otro presentándolo como un discurso sobre el otro, impidiendo de este modo pasar "a través del espejo" (Gruzinski 1988). Por ejemplo, la acción de los indios, descrita en el informe del corregidor, es ajustada a un cierto "modelo explicativo" a partir del cual se urde la secuencia de hechos: "los indios como gente incredula y que solo les lleva la atencion a la novedad pues carecen del entendimiento de luces para discernir y su unico objeto es propenso a la embriaguez empesaron...". ${ }^{100}$ Pero, como lo ha señalado Ginzburg, la influencia de tales filtros no debe ser exagerada, siempre y cuando consideremos que "pasar a través del espejo, captar a los indios fuera de Occidente es un ejercicio peligroso, la mayoría de las veces impracticable, globalmente ilusorio" pues del mundo indígena "sólo se captan reflejos a los que sin falta y de manera más o menos confusa se añade el nuestro"(Gruzinski 1988: $13,288)$.

La colonización de lo imaginario, el cambio y la reapropiación de y en los modos de expresión culturales de las sociedades indígenas, comportó caminos complejos, impredecibles y hasta no deseados por los colonizadores. Tal es el caso de prácticas culturales como las borracheras que experimentaron, con la introducción de nuevas bebidas alcohólicas, una suerte de "popularización" rompiendo, de este modo, con el privilegio que hasta entonces habían tenido los grupos gobernantes prehispánicos. Esta expansión, lo hemos sostenido citando a Saignes, implicó el acceso a un tipo de experiencia en el que los indios descubrían un espacio propio, autónomo y a veces subversivo. ${ }^{101}$

\footnotetext{
99 Ibid., foja $13 \mathrm{v}$.

100 Ibid., loc. cil.

101 Véase nota 67.
} 
Las borracheras permitían restituir una memoria, aunque fragmentada y fuertemente reelaborada, de un tiempo en el que la tierra les pertenecía a ellos con sus casas, estancias y ganados. De ahí que la borrachera colonial pueda asumirse como una "estructura conceptual" a partir de la cual podemos interpretar los actos (gestos y dichos) de los indígenas, sacándola de la esfera de los vicios en la que había sido localizada por las representaciones coloniales.

Sigamos explorando este espacio autónomo y subversivo que abre la borrachera, centrándonos en los indios ebrios y armados (de piedras y palos). Resulta desproporcionado que el comisionado de los oficiales reales haya concurrido a la casa del corregidor con una muchedumbre de indios, que bordeaba el centenar, en manifiesto estado de ebriedad. Los indios "jugaban su propio juego" en el cual la destitución del corregidor podía ser asumida como una derrota provocada en un enfrentamiento virtual no exento de ciertas notas de "realismo" --como el proporcionado por piedras, palos, vociferaciones, insultos, burlas, palabras denigrantes, e intentos de incendio, entre otros. Pero mucho de estos últimos gestos abrían otra dimensión. Por ejemplo, el notorio estado de ebriedad junto con el fuerte uso de mofas, burlas y palabras denigrantes, era una forma de rechazo a la represión que habían experimentado algunos modos de expresión culturales con el proyecto civilizador de Argumaniz.

\section{Siglas}

AGI: Archivo General de Indias, Sevilla.

AGNA: Archivo General de la Nación Argentina.

ANB: $\quad$ Archivo Nacional Boliviano, Sucre.

\section{Documentos}

"Expediente que acredita los méritos de don Franzisco de Argumaniz, corregidor que ha sido de la provincia de Atacama", AGI, Charcas 425, 34 fojas.

"Solicitud de Don Pablo Ramos, indio principal, hijo de Juan Esteban Ramos, cacique principal de la nobleza del pueblo de San Pedro de Atacama Alta", ANB, Catálogo de Tierras e Indios, E 1781, No 7, 8 fojas.

"Don Agustin Pieroso (Don Agustin Victorio Ramos) cacique principal de San Pedro de Atacama, declara ser injusta su sentencia de casicazgo, pues su abuelo fue cacique y gobernador con consentimiento de los virreyes", ANB, Catálogo de Tierras e Indias, E 1777, No 95, 2 fojas.

"Revisita de Atacama de 1751 y 1756 efectuada por el corregidor don Manuel Fernández Valdivieso", AGNA.

"Testimonio del expediente en que se comiciono a Don Josef Maria Paniagua para la aberiguacion y pacificacion del tumulto acaesido en la Provincia de Atacama en el asiento de Yngaguasi por el año de 1775", AGNA, Interior, Legajo 6, Expediente 8, 39 fojas.

"Testimonio de los autos criminales seguido de oficio de la Real Justicia en la Provincia de Atacama por el Theniente de Capitan General Corregidor de ella don Josef Maria de Paniagua", AGNA, Criminales, Legajo $10, \mathrm{~N}^{\circ} 3$. 


\section{BIBLIOGRAFIA}

ABERCROMBIE, T. Articulación doble y etnogénesis en Re1991 producción y transformación de las sociedades andinas, siglos XVI-XX, S. Moreno y F. Salomon, (Comps.), Abyayala, Quito, Ecuador, tomo I, pp. 197-212.

Caminos de la memoria en un cosmos colonizado. Poética de la memoria y la conciencia histórica en K'ulta. En Borrachera y memoria, Thierry Saignes, (Comp.), Hisbol//fea, Perú, pp. 139-185.

BAJTIN, M. La cultura popular en la Edad Media 1989 y el Renacimiento. EI contexto de Rabelais. Alianza Editorial, Madrid.

BORAH, W. El status jurídico de los indios en Nue1985 va España. En América Indígena, Vol. $\mathrm{XLV}, \mathrm{N}^{\circ} 2: 257-276$

CASTRO, N $1998 \mathrm{Ms}$

1999 Ms

Genealogía de una memoria, genealogía de un poder. La producción de memoria étnica colonial en el cacicazgo de Tacna, siglo XVIII

Escritura colonial e imaginarización. Ponencia presentada en el Seminario Epistemología y sujeto en las ciencias sociales, IEH, Universidad de Valparaíso.

CASTRO, V. y J. L. MARTÍNEZ. Poblaciones indígenas de 1996 Atacama. En Etnografía. Sociedades indígenas contemporáneas y su ideología, Jorge Hidalgo et al., (Eds.), Editorial Andrés Bello, Santiago, Chile, pp. 69-109.

COROMINAS, $\mathbf{J}$. Diccionario crítico etimológico de la 1954

DURSTON, A. Un régimen urbanístico en la América 1994 hispana colonial: El trazado en damero durante los siglos XVI y XVII. En Historia 28: $59-115$.

FABRE, D. Lo privado contra la costumbre. En His1992 toria de la vida privada. La comunidad, el estado y la familia en los siglos XVI-XVIII, Philippe Ariès y Georges Duby, (Eds.) Taurus, España, tomo 6, pp. 145-181.

FLORES, J. Hechicería e idolatría en Lima colonial 1991 (siglo XVIII). En Poder y violencia en los Andes, H. Urbano, compilador, Centro de Estudios Regionales Bartolomé de las Casas, Perú.
GADE, D. 1991

Reflexiones sobre el asentamiento andino de la época toledana al presente. En Reproducción y Transformación de las sociedades andinas siglos XVIXX, S. Moreno y F. Salomon, (Comps.), Editorial ABYA-YALA, Quito, tomo I. pp. $69-90$.

GANSTER, P. Religiosos. En Ciudades y sociedad en 1993 Latinoamérica colonial, Louisa S. Hoberman y Susan M. Socolow (Comps.), Fondo de Cultura Económica, México, pp. 141-174.

GEERTZ, C. Descripción densa: hacia una teoría in1992 terpretativa de la cultura. En La interpretación de las culturas, Editorial Gedisa, España, pp. 19-39.

GINSBURG, C. El queso y los gusanos. El cosmo se1997 gún un molinero del siglo XVI. Muchnik Editores, España.

GRAMSCI, A. El materialismo histórico y la filoso1958 fía de Benedetto Croce. Editorial Lautaro, Argentina.

GRUZINSKI, S. La colonización de lo imaginario. So1988 ciedades indígenas y occidentalización en el México español. Siglos XVIXVIII. Fondo de Cultura Económica, México.

HIDALGO, J. Fechas coloniales de fundación de Toco1981 naoy urbanización de San Pedro de Atacama. En Chungara 8: 255-264.

1982 Fases de la rebelión indígena de 1781 en el corregimiento de Atacama y esquema de la inestabilidad política que la precede, 1749-1781. En Chungara 9: 192-231.

1984 Descomposición cultural en Atacama en el siglo XVIII: Lengua, escuela, fugas y complementaridad ecológica. En Simposio Culturas Atacameñas. XLIV Congreso Internacional de Americanistas. Universidad del Norte. Antofagasta, pp. 221-249.

1985 Ecological complementarity and tribute in Atacama: 1683-1792. En Andean Ecology and Civilization, Shozo Masuda et al., (Eds.), University of Tokio Press, Japón, pp. 161-184.

1996 Resistencia y dominación en el cacicazgo de Pica. En Actas del III Congreso Internacional de Etnohistoria (en prensa). 
$1998 \mathrm{Ms}$ Proyectos escolares en el sur andino siglo XVIII. Ponencia presentada en el V Congreso Iberoamericano de Educación, Pontificia Universidad Católica de Chile.

1999 Ms Hegemonía e Identidad: La extirpación de la memoria andina después de la revuelta de Tupac Amaru. Ponencia presentada en las III Jornadas del Norte de Chile, siglos XVI-XIX, 13 y 14 de octubre, Universidad de Valparaíso.

HIDALGO, J, y CASTRO, N. Fiscalidad, punición y bruje1997 rías. San Pedro de Atacama, 1749-1755. En Estudios Atacameños 13: 35-65.

KLAIBER, J. Religión y justicia en Túpac Amaru. En 1982 Alpanchis 19:173-186.

LAENEC, $\mathrm{H}$ El bárbaro imaginario. Fondo de Cul1995 tura Económica, México.

LE ROY LADURIE, E. Entre los historiadores. Fondo de 1989 Cultura Económica, México.

MANDROU, R. Introducción a la Francia Moderna: 1962 1500-1640. Ensayo de psicología histórica. UTEHA, México

MARTÍNEZ, J. L. Textos y palabras. Cuatro documentos 1996 del siglo XVI. En Espacio, etnías, frontera. Atenuaciones políticas en el sur del Tawantinsuyu, siglos XV-XVIII, Ana $\mathrm{M}^{\mathrm{a}}$ Presta, editora y compiladora, Ediciones ASUR, Sucre. Bolivia.

1998 Pueblos del chañar y el algarrobo. Los atacamas en el siglo XVI. Publicación del Centro Barros Arana, Biblioteca Nacional, Chile.
MEMORIAS

1859

Memorias de los Virreyes que han gobernado el Perú. Librería Central de Felipe Bailly, Lima.

RANDALL. R. Los vasos. Cosmovisión y política de la 1997 embriaguez desde el inkanato hasta la colonia. En Borrachera y memoria, Thierry Saignes, (Comp)., Hisbol/Ifea, Perú, pp. 73-112.

RECOPILACIÓN Recopilación de las leyes de Indias [1681] 1973 Ediciones Cultura Hispánica, España.

ROMERO, J. L. Lationamérica: las ciudades y las 1986 ideas. Siglo XXI, Argentina.

SAIGNES, T. Borracheras andinas: ¿Por qué los in1998 dios ebrios hablan en español?. En Borrachera y memoria, Thierry Saignes (Comp.), Hisbol/Ifea, Perú, pp. 43-71.

SOLANO ASTABURUAGA, F. Diccionario geográfico de 1899 la República de Chile. Imprenta Brockauss, Leipzig, Santiago de Chile.

VAN KESSEL, J. Los aymaras contemporáneos de Chile 1994 En Etnografía. Sociedades indígenas contemporáneas y su ideología, Jorge Hidalgo et al., editores, Ed. Andrés BeIlo, Santiago, Chile, pp. 69-109.

VARGAS, R. Concilios limenses (1551-1772) Tomo 1952 II. Lima, sin pie de imprenta.

VOVELLE, $M . \quad$ El desvío de la historia en el redescubri1985 miento de la fiesta. En Ideología y mentalidades, Ariel Editorial, España.

WOLF, E. 1972

Pueblos y culturas de Mesoamérica Ediciones Era, México. 